\title{
DETECÇÃO E IDENTIFICAÇÃO MOLECULAR DE FITOPLASMAS ASSOCIADOS AO AMARELO DA VIDEIRA
}

\author{
RAQUEL DE CÁSSIA NERONI
}

Dissertação apresentada à Escola Superior de Agricultura "Luiz de Queiroz", Universidade de São Paulo, para obtenção do título de Mestre em Agronomia, Área de Concentração: Fitopatologia.

P I R A C I C A B A

Estado de São Paulo - Brasil

Dezembro - 2004 


\title{
DETECÇÃO E IDENTIFICAÇÃO MOLECULAR DE FITOPLASMAS ASSOCIADOS AO AMARELO DA VIDEIRA
}

\author{
RAQUEL DE CÁSSIA NERONI \\ Engenheiro Agrônomo
}

Orientador: Prof. Dr. IVAN PAULO BEDENDO

\begin{abstract}
Dissertação apresentada à Escola Superior de Agricultura "Luiz de Queiroz", Universidade de São Paulo, para obtenção do título de Mestre em Agronomia, Área de Concentração: Fitopatologia.
\end{abstract}

P I R A C I C A B A

Estado de São Paulo - Brasil

Dezembro - 2004 
Dados Internacionais de Catalogação na Publicação (CIP) DIVISÃO DE BIBLIOTECA E DOCUMENTAÇÃO - ESALQ/USP

Neroni, Raquel de Cássia

Detecção e identificação molecular de fitoplasmas associados ao amarelo da videira /

Raquel de Cássia Neroni. - - Piracicaba, 2004.

46 p. : il.

Dissertação (Mestrado) - - Escola Superior de Agricultura Luiz de Queiroz, 2004.

Bibliografia.

1. Amarelos - Doença de planta 2. Aspecto econômico 3. DNA 4. Eletroforese em gel 5. Fitoplamas 6. Fitossanidade 7. Marcador molecular 8. Mollicutes 9. Uva I. Título

CDD 634.8

"Permitida a cópia total ou parcial deste documento, desde que citada a fonte - O autor" 
Aos meus pais, Antônio e Marta,

pelo amor, apoio e confiança que

permitiram meu crescimento

como ser humano, DEDICO.

À minha irmã Rafaela, ao meu namorado Eduardo

e ao meu cunhado André pelo companheirismo de todas as horas,

OFEREÇO. 


\section{AGRADECIMENTOS}

A Deus, pelo força concedida nos momentos de desânimo e decepção, tornando possível a conclusão deste trabalho;

Ao Prof. Dr. Ivan Paulo Bedendo, pela preciosa orientação, pela confiança, dedicação e incentivo;

Ao pesquisador científico Dr. Hugo Kuniyuki pela gentileza de fornecer o material de videira, pela condução dos testes de enxertia e pela atenção dada;

Ao Prof. Dr. Nelson Massola Júnior pela condução de todo o trabalho de microscopia eletrônica;

A Fundação de Amparo a Pesquisa do Estado de São Paulo-FAPESP, pela concessão da bolsa de mestrado, destinada à realização deste trabalho;

A todos os funcionários e professores do Setor de Fitopatologia da ESALQ/USP, pelo companheirismo e amizade;

As minhas amigas Marisa e Mariana, pelos bons momentos juntas;

Aos meus amigos do Laboratório de Fitopatologia Molecular, Adriana, Ana Paula, Eliane, Isolda, Jorge, Luiz Fernando e Ricardo pelo bom convívio, amizade e respeito;

A todos os amigos dos demais laboratórios do Setor de Fitopatologia da ESALQ/USP, que contribuíram para a realização deste trabalho;

Obrigada. 


\section{SUMÁRIO}

Página

LISTA DE FIGURAS................................................................................... vii

LISTA DE TABELAS................................................................................ xi

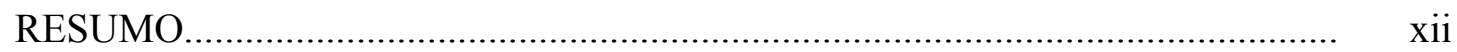

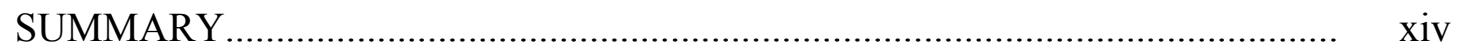

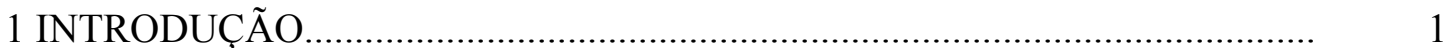

2 REVISÃO DE LITERATURA................................................................... 3

2.1 Fitoplasmas como agentes patogênicos de plantas.......................................... 3

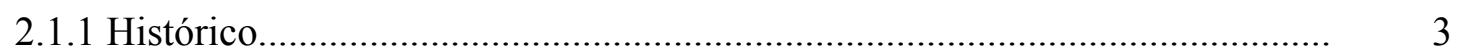

2.1.2 Sintomatologia e diagnose de doenças associadas a fitoplasmas.................... 4

2.2 A cultura da videira................................................................................. 5

2.2.1 Aspectos econômicos............................................................................. 5

2.2.2 Aspectos fitossanitários.............................................................................. 6

2.3 Amarelos da videira................................................................................ 7

2.3.1 Aspectos históricos................................................................................ 7

2.3.2 Etiologia dos amarelos da videira.................................................................... 8

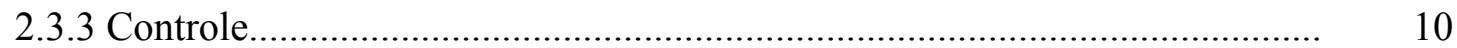

3 MATERIAL E MÉTODOS.................................................................... 11

3.1 Amostras de plantas de videira...................................................................... 11

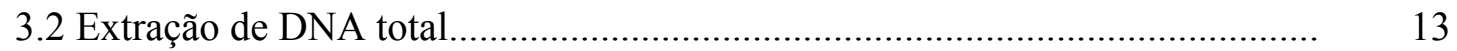

3.2.1 Extração rápida........................................................................................... 13

3.2.2 Extração completa...................................................................................... 14

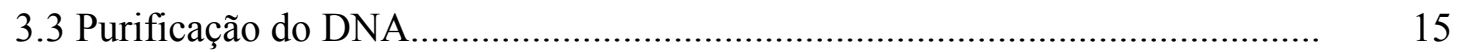


3.4 Detecção de fitoplasmas por PCR ..................................................................... 15

3.5 Identificação de fitoplasma por PCR .............................................................. 16

3.6 Eletroforese em gel de agarose.............................................................. 17

3.7 Identificação dos fitoplasmas por análise de RFLP......................................... 17

4 RESULTADOS E DISCUSSÃO................................................................. 19

4.1 Detecção através de duplo PCR ...................................................................... 19

4.2 Identificação de fitoplasmas por PCR............................................................. 23

4.3 Identificação de fitoplasma através da análise de RFLP.................................. 28

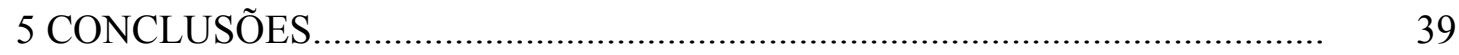

REFERÊNCIAS BIBLIOGRÁFICAS......................................................... 40 


\section{LISTA DE FIGURAS}

Página

1 Amostras de videira coletadas em 2000 e 2004 positivas para a presença de fitoplasmas, detectados por duplo PCR. $\mathrm{M}=$ Marcador molecular $1 \mathrm{~Kb}$ ladder; $\mathrm{Mi}=$ padrão positivo de milho; $\mathrm{Ch}=$ padrão positivo de chuchu; $\mathrm{Vs}=$ padrão negativo videira sadia; $1=$ Itália, Jundaí-SP; $2=$ Benitaka LD1587, Londrina-PR; 3= Itália PS1788, Pilar do Sul-SP; 4= Benitaka, Marialva-PR; 5= Itália 08.1210, Campinas-SP;10A= Brasil1780, MarialvaPR

2 Amostras de videira coletadas em 2001, 2003 e 2004 positivas para a presença de fitoplasmas, detectados por duplo PCR. M= Marcador molecular $1 \mathrm{~Kb}$ ladder; $\mathrm{Mi}=$ padrão positivo de milho; $\mathrm{Ch}=$ padrão positivo de chuchu; $\mathrm{Vs}=$ padrão negativo videira sadia; $6=$ Benitaka 08.3136, Campinas-SP; 7= Cabernet Franc CF1261, Campinas-SP; 8= Maria LV1459, Jundiaí-SP; 9= Seedling Brasil, Campinas-SP; 10B= Brasil 1780, Marialva-PR

3 e 4 Identificação de fitoplasmas presentes em amostras de videira, através de PCR usando iniciadores específicos para o grupo 16SrI e 16SrIII, respectivamente. $\mathrm{M}=$ marcador molecular $1 \mathrm{~Kb}$ ladder; $\mathrm{Mi}=$ amostra de milho (16SrI); Ch= amostra de chuchu (16SrIII); 6= Benitaka 08.3136, Campinas-SP; 7= Cabernet Franc CF1261, Campinas-SP; 8= Maria LV1459, Jundiaí-SP; 9= Seedling Brasil, Campinas-SP; 10B= Brasil 1780, Marialva-PR 
5 e 6 Identificação de fitoplasmas presentes em amostras de videira, através de PCR usando iniciadores específicos para o grupo 16SrI e 16SrIII, respectivamente. $\mathrm{M}=$ marcador molecular $1 \mathrm{~Kb}$ ladder; $\mathrm{Mi}=$ amostra de milho (16SrI); $\mathrm{Ch}=$ amostra de chuchu (16SrIII); 1= Itália, Jundaí-SP; 2= Benitaka LD 1587, Londrina-PR; 3= Itália PS1788, Pilar do Sul-SP; 4= Benitaka, Marialva-PR; 5= Itália 08.1210, Campinas-SP; 10A= Brasil 1780, Marialva-PR

7 Produtos de digestão obtidos com a enzima KpnI. Análise dos produtos de duplo PCR conduzido com os pares de nucleotídeos P1/P7 e R16 F2n/R2, utilizando DNA extraído de plantas de milho com sintomas de enfezamento, como representante do grupo $16 \mathrm{SrI}$ e DNA extraído de plantas de videira com sintomas de amarelo. $\mathrm{M}=$ padrão de peso molecular, utilizando $\mathrm{o}$ marcador $\Phi$ X174RFHaeIII (1353pb, 1078pb, 872pb, 603pb, 310pb, 271pb, 281pb, 234pb, 194pb, 118pb, 72pb); 6= Benitaka 08.3136, Campinas-SP; 7= Cabernet Franc CF1261, Campinas-SP; 8= Maria LV1459, Jundiaí-SP; 9= Seedling Brasil, Campinas-SP; 10B = Brasil 1780, Marialva-PR; $\mathrm{Mi}=$ milho, representante do grupo $16 \mathrm{SrI}$

8 Produtos de digestão obtidos com a enzima RsaI. Análise dos produtos de duplo PCR conduzido com os pares de nucleotídeos P1/P7 e R16 F2n/R2, utilizando DNA extraído de plantas de milho com sintomas de enfezamento, como representante do grupo 16SrI e DNA extraído de plantas de videira com sintomas de amarelo. 6= Benitaka 08.3136, Campinas-SP; 7= Cabernet Franc CF1261, Campinas-SP; 8= Maria LV1459, Jundiaí-SP; 9= Seedling Brasil, Campinas-SP; 10B $=$ Brasil 1780, Marialva-PR; $\mathrm{Mi}=$ milho, representante do grupo $16 \mathrm{SrI} ; \mathrm{M}=$ padrão de peso molecular, utilizando o marcador $\Phi$ X174RFHaeIII (1353pb, 1078pb, 872pb, 603pb, 310pb, 271pb, $281 \mathrm{pb}, 234 \mathrm{pb}, 194 \mathrm{pb}, 118 \mathrm{pb}, 72 \mathrm{pb})$

9 Produtos de digestão obtidos com a enzima HpaII. Análise dos produtos de duplo PCR conduzido com os pares de nucleotídeos P1/P7 e R16 F2n/R2, utilizando DNA extraído de plantas de milho com sintomas de enfezamento, 
como representante do grupo $16 \mathrm{SrI}$ e DNA extraído de plantas de videira com sintomas de amarelo. $6=$ Benitaka 08.3136, Campinas-SP; $7=$ Cabernet Franc CF1261, Campinas-SP; 8= Maria LV1459, Jundiaí-SP; 9= Seedling Brasil, Campinas-SP; 10B $=$ Brasil 1780, Marialva-PR; $\mathrm{Mi}=$ milho, representante do grupo $16 \mathrm{SrI} ; \mathrm{M}=$ padrão de peso molecular, utilizando o marcador $\Phi$ X174RFHaeIII (1353pb, 1078pb, 872pb, 603pb, 310pb, 271pb, $281 \mathrm{pb}, 234 \mathrm{pb}, 194 \mathrm{pb}, 118 \mathrm{pb}, 72 \mathrm{pb})$

10 Produtos de digestão obtidos com a enzima HinfI. Análise dos produtos de duplo PCR conduzido com os pares de nucleotídeos P1/P7 e R16 F2n/R2, utilizando DNA extraído de plantas de milho com sintomas de enfezamento, como representante do grupo $16 \mathrm{SrI}$ e DNA extraído de plantas de videira com sintomas de amarelo. $6=$ Benitaka 08.3136, Campinas-SP; $7=$ Cabernet Franc CF1261, Campinas-SP; 8= Maria LV1459, Jundiaí-SP; 9= Seedling Brasil, Campinas-SP; 10B $=$ Brasil 1780, Marialva-PR; $\mathrm{Mi}=$ milho, representante do grupo $16 \mathrm{SrI} ; \mathrm{M}=$ padrão de peso molecular, utilizando o marcador $\Phi$ X174RFHaeIII (1353pb, 1078pb, 872pb, 603pb, 310pb, 271pb, $281 \mathrm{pb}, 234 \mathrm{pb}, 194 \mathrm{pb}, 118 \mathrm{pb}, 72 \mathrm{pb})$

11 Produtos de digestão obtidos com a enzima MboI. Análise dos produtos de duplo PCR conduzido com os pares de nucleotídeos P1/P7 e R16 F2n/R2, utilizando DNA extraído de plantas de milho com sintomas de enfezamento, como representante do grupo 16SrI e DNA extraído de plantas de videira com sintomas de amarelo. $6=$ Benitaka 08.3136, Campinas-SP; $7=$ Cabernet Franc CF1261, Campinas-SP; 8= Maria LV1459, Jundiaí-SP; 9= Seedling Brasil, Campinas-SP; 10B = Brasil 1780, Marialva-PR; $\mathrm{Mi}=$ milho, representante do grupo $16 \mathrm{SrI}$; $\mathrm{M}=$ padrão de peso molecular, utilizando o marcador $\Phi$ X174RFHaeIII (1353pb, 1078pb, 872pb, 603pb, 310pb, 271pb, $281 \mathrm{pb}, 234 \mathrm{pb}, 194 \mathrm{pb}, 118 \mathrm{pb}, 72 \mathrm{pb})$ 
12 Produtos de digestão obtidos com a enzima MseI. Análise dos produtos de duplo PCR conduzido com os pares de nucleotídeos P1/P7 e R16 F2n/R2, utilizando DNA extraído de plantas de milho com sintomas de enfezamento, como representante do grupo $16 \mathrm{SrI}$ e DNA extraído de plantas de videira com sintomas de amarelo. 6= Benitaka 08.3136, Campinas-SP; 7= Cabernet Franc CF1261, Campinas-SP; 8= Maria LV1459, Jundiaí-SP; 9= Seedling Brasil, Campinas-SP; 10B = Brasil 1780, Marialva-PR; $\mathrm{Mi}=$ milho, representante do grupo $16 \mathrm{SrI} ; \mathrm{M}=$ padrão de peso molecular, utilizando o marcador $\Phi$ X174RFHaeIII (1353pb, 1078pb, 872pb, 603pb, 310pb, 271pb, 281pb, 234pb, 194pb, 118pb, 72pb)

13 Produtos de digestão obtidos com a enzima AluI. Análise dos produtos de duplo PCR conduzido com os pares de nucleotídeos P1/P7 e R16 F2n/R2, utilizando DNA extraído de plantas de milho com sintomas de enfezamento, como representante do grupo $16 \mathrm{SrI}$ e DNA extraído de plantas de videira com sintomas de amarelo. 6= Benitaka 08.3136, Campinas-SP; 7= Cabernet Franc CF1261, Campinas-SP; 8= Maria LV1459, Jundiaí-SP; 9= Seedling Brasil, Campinas-SP; 10B = Brasil 1780, Marialva-PR; $\mathrm{Mi}=$ milho, representante do grupo $16 \mathrm{SrI} ; \mathrm{M}=$ padrão de peso molecular, utilizando o marcador $\Phi$ X174RFHaeIII (1353pb, 1078pb, 872pb, 603pb, 310pb, 271pb, $281 \mathrm{pb}, 234 \mathrm{pb}, 194 \mathrm{pb}, 118 \mathrm{pb}, 72 \mathrm{pb})$

14 Produtos de digestão obtidos com a enzima HhaI. Análise dos produtos de duplo PCR conduzido com os pares de nucleotídeos P1/P7 e R16 F2n/R2, utilizando DNA extraído de plantas de milho com sintomas de enfezamento, como representante do grupo $16 \mathrm{SrI}$ e DNA extraído de plantas de videira com sintomas de amarelo. 6= Benitaka 08.3136, Campinas-SP; $7=$ Cabernet FrancCF1261, Campinas-SP; 8= Maria LV1459, Jundiaí-SP; 9= Seedling Brasil, Campinas-SP; 10B $=$ Brasil 1780, Marialva-PR; $\mathrm{Mi}=$ milho, representante do grupo $16 \mathrm{SrI}$; $\mathrm{M}=$ padrão de peso molecular, utilizando o marcador $\Phi$ X174RFHaeIII (1353pb, 1078pb, 872pb, 603pb, 310pb, 271pb, $281 \mathrm{pb}, 234 \mathrm{pb}, 194 \mathrm{pb}, 118 \mathrm{pb}, 72 \mathrm{pb})$ 


\section{LISTA DE TABELAS}

Página

1 Relação das variedades de videira provenientes de diversas localidades, amosradas em diferentes anos e avaliadas para a presença de fitoplasmas nos tecidos

2 Relação das plantas de videira nas quais foram detectados fitoplasmas através de testes de PCR

3 Identificação de fitoplasmas presentes em amostras de videira, através de PCR usando iniciadores para grupos específicos. 


\section{DETECÇÃO E IDENTIFICAÇÃO MOLECULAR DE FITOPLASMAS ASSOCIADOS AO AMARELO DA VIDEIRA}

Autora: RAQUEL DE CÁSSIA NERONI

Orientador: Prof. Dr. IVAN PAULO BEDENDO

\section{RESUMO}

Os amarelos estão associados a fitoplasmas, procariotos pertencentes à classe Mollicutes que não possuem parede celular e habitam o floema de plantas. Os danos causados pelas doenças de etiologia fitoplasmática são relevantes e podem ocorrer em diversas espécies economicamente importantes. Em videira, pesquisas realizadas em várias partes do mundo têm relatado a presença das doenças do tipo "amarelo", porém, no Brasil, estas doenças ainda não foram relatadas para esta cultura. Em vinhedos comerciais localizados nos Estados de São Paulo e Paraná têm sido observadas plantas com sintomas semelhantes àqueles provocados por fitoplasmas em outros países. Estes sintomas têm sido caracterizados por amarelecimento e ou avermelhamento foliar, necrose do limbo e rachaduras nas nervuras principais. Com o objetivo de detectar e identificar molecularmente fitoplasmas associados a estes tipos de sintomas, folhas e ramos foram amostrados a partir de plantas sintomática e assintomáticas. A detecção foi conduzida com PCR duplo usando-se os iniciadores $\mathrm{R} 16 \mathrm{mF} 1 / \mathrm{mR} 2$ ou P1/P7 na primeira reação e R16 F2n/R2 na segunda reação. A identificação 
foi realizada através de PCR duplo com iniciadores específicos e análises de RFLP com as enzimas de restrição AluI, RsaI, KpnI, MseI, HhaI, HpaII, HinfI e MboI. Em 23 plantas amostradas, fitoplasmas foram detectados em 10 delas, através da amplificação do $16 \mathrm{~S}$ rDNA, visualizado em gel de agarose na forma de bandas de $1,2 \mathrm{~Kb}$. A identificação por PCR demonstrou que os fitoplasmas associados ao amarelo da videira pertenciam aos grupos 16SrI e 16SrIII. As análises dos perfis eletroforéticos obtidos com o uso da técnica de RFLP revelaram a presença de fitoplasmas afiliados ao subgrupo 16SrI-B. A constatação de fitoplasmas pertencentes a estes dois grupos nas plantas amostradas demonstraram a ocorrência da doença conhecida como amarelo da videira nos Estados de São Paulo e Paraná. As pesquisas desenvolvidas neste trabalho vêm contribuir para aumentar os conhecimentos sobre o papel e a diversidade dos fitoplasmas no agroecossistema brasileiro. 


\section{DETECTION AND MOLECULAR IDENTIFICATION OF PHYTOPLASMAS ASSOCIATED TO GRAPEVINE YELLOW DISEASE}

Author: RAQUEL DE CÁSSIA NERONI

Adviser: Prof. Dr. IVAN PAULO BEDENDO

\section{SUMMARY}

Yellows diseases are associated with phytoplasmas, wall-less prokaryotes, inhabitant of phloem vessels. Damage caused by these diseases are relevant for some important cultivated botanical species. Grapevine yellows diseases have been observed in several areas of the world, but in Brazil the presence of these diseases had not been reported yet. In vineyards located in São Paulo and Paraná States, plants exhibiting symptoms similar those observed in grapevines from other countries have been observed. The symptoms were characterized by yellowing or redding of leaf blade and ribs, leaf blade necrosis and main ribs fissures. In order to detect and identify phytoplasmas associated with those kind of symptoms, leaves and stems were sampled from symptomatic and asymptomatic plants. The phytoplasma detection was conducted with nested PCR using the primer pairs $\mathrm{R} 16 \mathrm{mF} 1 / \mathrm{mR} 2$ or $\mathrm{P} 1 / \mathrm{P} 7$ for first reaction and $16 \mathrm{~F} 2 \mathrm{n} / \mathrm{R} 2$ for second reaction. The identification was carried out by nested PCR with group-specifc primer pairs and RFLP analyses with enzymes AluI, RsaI, KpnI, MseI, HhaI, HpaII, HinfI and MboI. From a total of 23 samples analysed, phytoplasmas were detected in 10 of them, through amplification of the $16 \mathrm{~S} \mathrm{rDNA}$, visualized through a $1.2 \mathrm{~Kb}$ band in agarose gel. The identification by PCR demonstrated that phytoplasmas associated with grapevine yellow belong to $16 \mathrm{SrI}$ and $16 \mathrm{SrIII}$ groups. Analyses of electrophoretic profiles 
revealed the presence of phytoplasmas affiliated to $16 \mathrm{SrI}-\mathrm{B}$ subgroup. The presence of phytoplasmas belonging to these two groups in the sampled plants demonstrated the occurrence of yellow disease in grapevine in São Paulo and Paraná States. The investigation conducted in the present work contributed to the knowledgement of the role and the diversity of phytoplasmas in Brasilian ecosystem. 


\section{INTRODUÇÃO}

Fitoplasmas são organismos unicelulares, procariotos, sem parede celular. Até hoje, não são cultiváveis em meio de cultura, o que dificulta a complementação de diagnoses de doenças feitas com base na sintomatologia. Por esta razão, a demonstração de sua associação com plantas doentes tem sido feita através de sua detecção nos tecidos infectados.

Tradicionalmente, a detecção de fitoplasmas em plantas doentes tem sido realizada através de microscopia eletrônica. Mais recentemente, metodologias moleculares estão sendo utilizadas tanto para detecção como para identificação de fitoplasmas, destacando-se as técnicas de PCR ("Polymerase Chain Reaction") e de RFLP ("Restriction Fragment Length Polymorphism"). A caracterização molecular por RFLP tem se mostrado extremamente útil e eficiente na identificação de fitoplasmas, permitindo a classificação dos mesmos em grupos reconhecidos internacionalmente.

$\mathrm{Na}$ videira, fitoplasmas estão associados a doenças de grande importância econômica, denominadas de flavescência dourada e amarelos da videira. A ocorrência destas doenças tem sido registrada em diversas partes do mundo, como na Europa, nos Estados Unidos e na Austrália. No Brasil, plantas apresentando sintomas semelhantes àqueles relatados em outros países têm sido observadas em vinhedos instalados nos Estados de São Paulo e Paraná. Este fato tem despertado a atenção de produtores e pesquisadores, justificando uma investigação mais detalhada, no sentido de esclarecer a etiologia destas doenças que ocorrem nesta importante espécie cultivada no território brasileiro.

Neste trabalho, plantas de videira exibindo sintomas do tipo amarelo foram submetidas a testes de PCR, na tentativa de associar sintomas com a presença de 
fitoplasmas. Após a demonstração da associação entre fitoplasmas e plantas doentes, estes fitoplasmas foram identificados molecularmente, através de análise de RFLP, e classificados de acordo com os parâmetros atualmente adotados. Portanto, os objetivos visados foram:

- demonstrar a associação entre fitoplasmas e sintomas de amarelo;

- determinar a que grupo(s) da classificação pertencem os fitoplasmas ocorrentes nas plantas amostradas;

- relacionar os fitoplasmas presentes nos dois estados brasileiros com aqueles relatados em outros países. 


\section{REVISÃO DE LITERATURA}

\subsection{Fitoplasmas como agentes patogênicos de plantas}

\subsubsection{Histórico}

Por décadas, as enfermidades genericamente conhecidas como amarelos foram atribuídas aos vírus. Em 1967, observando tecidos de plantas doentes ao microscópio eletrônico, pesquisadores japoneses evidenciaram a presença de corpúsculos arredondados semelhantes aos já conhecidos micoplasmas patogênicos aos animais (Doi et al., 1967). Estes microrganismos foram identificados como MLOs ("Mycoplasma Like Organisms") e a partir de 1994, o termo fitoplasma passou a ser empregado para designar estes patógenos vegetais (Sears \& Kirkpatrick, 1994). Fitoplasmas pertencem à classe Mollicutes, habitam os vasos do floema e são transmitidos, em condições naturais, por cigarrinhas. Até hoje, seu isolamento em meio de cultura não tem sido possível, fato este que dificulta os estudos das doenças associadas a estes patógenos.

As doenças associadas a fitoplasmas têm se mostrado bastante destrutivas, causando perdas relevantes. Já na década de oitenta, centenas de doenças eram referidas como sendo causadas por estes agentes (McCoy et al., 1989). No âmbito mundial, são exemplos o superbrotamento da batata, o declínio da pereira, os amarelos da videira, o enfezamento vermelho do milho, o nanismo do arroz, o superbrotamento do sândalo, os amarelos do pessegueiro, o superbrotamento e o lenho mole da macieira, o amarelo letal do coqueiro, entre outros (Davis, 1995). No Brasil, uma diversidade de gêneros e espécies vegetais são afetadas por doenças associadas a fitoplasmas, sendo exemplos o 
superbrotamento do maracujazeiro, da mandioca, do feijoeiro e da soja, o irizado do chuchuzeiro, o enfezamento vermelho do milho, o cálice gigante do tomateiro, o declínio do caquizeiro entre outras (Kitajima, 1995).

\subsubsection{Sintomatologia e diagnose de doenças associadas a fitoplasmas}

De maneira geral, os sintomas apresentados pelas plantas doentes são clorose foliar, superbrotamento de ramos, subdesenvolvimento da planta ou de suas partes, queda de folhas, flores e frutos jovens, esterilidade de órgãos florais e declínio da planta. No entanto, todos estes sintomas podem também ser provocados por outros agentes como vírus, bactérias fastidiosas, anomalia genética, desbalanço nutricional e fatores do ambiente, como compactação do solo e estresses de natureza diversa. Assim, a detecção de fitoplasmas em plantas suspeitas é um complemento à diagnose feita com base na sintomatologia, tornando-a mais confiável.

A detecção de fitoplasmas em plantas pode ser feita por microscopia eletrônica de transmissão (Kitajima, 1994), porém, segundo Barros (1997), esta técnica torna-se inviável para ser adotada como método de rotina, devido ao custo elevado do equipamento e a exigência de mão-de-obra altamente qualificada. Ainda, a observação de fitoplasma por microscopia eletrônica não possibilita sua identificação, devido a impossibilidade de diferenciação morfológica. Dessa forma, o uso das técnicas moleculares na diagnose tem sido largamente explorado nos laboratórios de patologia vegetal das universidades, institutos de pesquisa e serviços de inspeção e quarentena de plantas no mundo inteiro. Tradicionalmente, a identificação e classificação de fitoplasmas foi baseada primeiramente nas propriedades biológicas, como os sintomas induzidos em plantas infectadas, gama de plantas hospedeiras e relação com insetos vetores (Chiykowski \& Sinha, 1989).

As técnicas de PCR ("Polymerase Chain Reaction") e de RFLP ("Restriction Fragment Length Polymorphisms") têm predominado quando o objetivo é detectar e identificar fitoplasmas. O PCR é um método rápido e sensível permitindo a detecção de fitoplasmas em plantas e insetos vetores em algumas horas, até mesmo quando a concentração do patógeno nos tecidos é baixa (Henson \& French, 1993; Schaff et al., 
1992). Já o RFLP tem se mostrado muito eficiente para a identificação, permitindo a classificação de fitoplasmas em grupos (Lee et al., 1998). A partir da classificação, é possível determinar o grau de similaridade entre fitoplasmas e mesmo a identificação de fitoplasmas representantes de novos grupos, caso não se enquadre em nenhum dos grupos existentes (Montano et al., 2000; Montano et al., 2001). A identificação pode contribuir para demonstrar a ocorrência de infecções mistas de fitoplasmas em um único hospedeiro ou a ocorrência de um mesmo fitoplasma em espécies vegetais distintas (Davis, 1995).

\subsection{A cultura da videira}

A videira cultivada pertence à família Vitaceae, possui 11 gêneros e cerca de 450 espécies. O gênero Vitis é o mais importante, abrangendo cerca de 50 espécies, sendo muitas silvestres (Simão, 1998).

No Brasil, a videira foi introduzida em 1532 através da expedição de Martim Afonso de Souza. As mudas, oriundas de Portugal não chegaram a constituir uma cultura de importância econômica em nosso país devido a falta de adaptação das variedades européias (Vitis vinifera) as nossas condições ambientais. A cultura só tomou impulso no século XIX, quando foram trazidas para o Brasil videiras americanas mais rústicas, de maior resistência a pragas e doenças, apresentando maior adaptação ao ambiente brasileiro (Corrêa \& Boliani, 2001).

\subsubsection{Aspectos econômicos}

As videiras costumam ser divididas em dois grandes grupos, aquelas que produzem uvas de mesa e as uvas para vinho e outros fins industriais. A maior parte da produção mundial das videiras permanece destinada à produção de vinho. Calcula-se que cerca de $80 \%$ do total produzido anualmente é transformado em vinhos ou outros tipos de bebidas alcóolicas e 10\% é consumido in natura. A Europa é responsável por $51 \%$ da produção mundial de uvas, sendo a Itália o maior produtor mundial com 9.731 .580 toneladas no ano de 2000 (Corrêa \& Boliani, 2001). 
O cultivo da videira somente adquiriu importância econômica no Brasil com a imigração italiana, que se estabeleceu nos Estados do Rio Grande do Sul e São Paulo. As uvas produzidas nestes estados são utilizadas predominantemente para a produção de vinhos e mercado de frutas para mesa, respectivamente.

No ano de 2001, o Brasil apresentou uma área colhida de 63.288 hectares e uma produção de 1.058.579 toneladas. Dentre os estados brasileiros, os maiores produtores de uva são o Rio Grande do Sul, São Paulo, Pernambuco, Paraná e Bahia (Agrianual, 2004).

As exportações brasileiras se destinam, em sua maior parte, para a Europa, sendo os países Baixos, Reino Unido e Alemanha os principais compradores. Em 2002, o Brasil exportou 26.457 toneladas de uvas frescas e secas, correspondendo a 33.843 milhões de dólares. Quanto às importações, em 2002 o Brasil importou 24.797 toneladas de uvas frescas e secas, oriundas principalmente do Chile, Argentina e Turquia, correspondendo a 17.159 milhões de dólares (Agrianual, 2004).

\subsubsection{Aspectos fitossanitários}

Segundo Gallotti et al. (2002), nas regiões vitícolas brasileiras, as doenças constituem-se em um dos maiores entraves para a cultura. As doenças fúngicas são as mais prevalecentes e causam os maiores danos, tanto que a omissão das medidas de controle pode acarretar em perdas totais. O controle químico foi por muitas vezes utilizado como medida única no controle das doenças fúngicas da videira, porém, o controle integrado, isto é, a utilização das várias formas de controle associadas, além de reduzir o uso de fungicidas, diminui o risco de contaminação do aplicador e do consumidor e reduz a poluição ambiental.

Além das doenças fúngicas, as viroses são outro ponto importante na cultura. Segundo Kuniyuki (2001), a videira é uma planta comumente infectada por vírus em São Paulo e em outras áreas vitícolas do Brasil e do mundo. Estes patógenos vêm sendo considerados como um dos importantes fatores de natureza fitossanitária que afetam o vigor e a longevidade produtiva das plantas, diminuem a produção e reduzem a cotação do produto no mercado. As principais viroses da videira já foram constatadas no Brasil e a importância dessas doenças é semelhante a atribuída em outros países vitícolas, já que 
a viticultura nacional resulta da multiplicação de clones de variedades de copa e de porta-enxerto, introduzidos há muitos anos, de regiões que hoje enfrentam esses problemas.

Os fitoplasmas, assim como os vírus, são patógenos biotróficos, que vivem nos vasos do floema das plantas e podem ser perpetuados por meio da propagação vegetativa, comum na cultura. Daí a importância em saber se o patógeno está presente em plantas, que podem estar sendo usadas como matrizes na produção de mudas.

\subsection{Amarelos da videira}

\subsubsection{Aspectos históricos}

$\mathrm{Na}$ videira, duas doenças do tipo "amarelos" têm sido registradas, sendo uma delas chamada de flavescência dourada e a outra denominada de amarelo da videira (Caudwell \& Martelli, 1993).

A flavescência dourada foi relatada pela primeira vez em 1954 (Caudwell, 1957), no sudoeste da França, de onde se disseminou rapidamente para o sul do país e norte da Itália. A flavescência dourada foi aparentemente introduzida na Europa a partir da região dos Grandes Lagos, nos Estados Unidos, habitat natural da cigarrinha Scaphoideus titanus, vetora da doença e onde também ocorre uma doença similar em Vitis vinifera (Caudwell \& Dalmasso, 1985; Pearson et al., 1985).

Algumas cultivares de videira não são suscetíveis à flavescência dourada e não mostram sintomas. Por ser muito sensível à doença, a cultivar Baco 22A é considerada como principal indicadora, porém, outras cultivares como 'Aramon', 'Chardonnay', 'Sangiovese' e 'Alicante Bouchet' também apresentam sensibilidade e podem ser usadas como indicadoras. Os sintomas geralmente aparecem no final da primavera e se manifestam na forma de encurtamento de internódios, enrolamento de folhas, queda de brotos, seca das inflorescências, declínio e morte da planta. As variedades brancas apresentam amarelecimento das folhas seguido de necrose, enquanto as variedades tintas exibem avermelhamento foliar e posterior necrose de tecido. Manchas pontuais negras 
aparecem na região dos internódios e a lignificação dos ramos se dá de forma irregular (Caudwell, 1988).

$\mathrm{O}$ amarelo da videira apresenta sintomas idênticos àqueles da flavescência dourada, no entanto estas doenças diferem em alguns aspectos relacionados à suscetibilidade das cultivares, epidemiologia e transmissão pelo vetor Scaphoideus titanus. Quanto à transmissão, a cigarrinha S. titanus não transmite o agente do amarelo. A variedade 'Chardonnay' é usada como indicadora.

Sintomas similares aos relatados inicialmente na França (Caudwell, 1961), têm sido relatados em muitos outros países, como Alemanha, Suíça, Itália, Grécia, Israel, Chile, Argentina e Austrália (Caudwell, 1988).

\subsubsection{Etiologia dos amarelos da videira}

Alguns estudos têm mostrado que os amarelos da videira são um complexo de doenças que, embora semelhantes quanto à sintomatologia, são causados por fitoplasmas molecularmente distintos, os quais variam em função da área geográfica (Caudwell, 1993). Análises de RFLP revelaram uma estreita relação filogenética entre os agentes causais da doença que ocorrem na Alemanha, França e em vários outros países (Daire et al., 1993). Prince et al. (1993) detectaram a associação de dois fitoplasmas diferentes com os amarelos da videira na Virgínia, EUA, e identificou os fitoplasmas como membros dos grupos 16SrI (“aster yellows group") e 16SrIII ("peach X-disease group"), porém, a identificação dos fitoplasmas até o nível de subgrupos não foi relatada. Segundo Davis et al. (1998), o conhecimento das afiliações de fitoplasmas em subgrupos é significante porque facilita a identificação futura de insetos vetores e a gama de plantas hospedeiras alternativas ainda desconhecidas.

Com base nas análises de RFLP do 16S rDNA, o fitoplasma da flavescência dourada tem sido classificado no grupo $16 \mathrm{SrV}$ ("elm yellows group"), subgrupos C (Lee et al., 1998; Martini \& Murari, 1999; Davis \& Dally, 2001) e D (Martini \& Murari, 1999; Davis \& Dally, 2001); o fitoplasma associado ao amarelo na Europa, tem sido classificado no grupo 16SrXII ("stolbur group"), subgrupo A (Lee et al., 1998); o fitoplasma associado ao amarelo que ocorre na Austrália ("Candidatus Phytoplasma 
australiense") está classificado no grupo 16SrXII, subgrupo B (Davis et al., 1997; Lee et al., 1998) e os fitoplasmas agentes dos amarelos nos Estados Unidos foram classificados nos grupos 16SrI, subgrupo A e 16SrIII, subgrupo I (Davis et al., 1998). Portanto, apesar dos sintomas serem similares há uma diversidade de fitoplasmas associados aos amarelos da videira nas diferentes regiões do mundo.

O fato das plantas infectadas pela flavescência dourada e outros amarelos da videira exibirem sintomas aparentemente idênticos, torna importante o esclarecimento da identidade do fitoplasma que está infectando plantas com esses sintomas. A ocorrência de infecções mistas, ou seja, mais de um grupo ou mais de um subgrupo de fitoplasmas presentes na mesma planta também tem sido relatada. Alma et al. (1996) confirmaram a infecção mista em videiras na Itália pelos grupos $16 \mathrm{SrI}$ e $16 \mathrm{SrV}$ e pelos subgrupos $16 \mathrm{SrI}-\mathrm{B}$ e $16 \mathrm{SrI}-\mathrm{G}$, em áreas onde se observou a presença da cigarrinha $S$. titanus, vetora do fitoplasma da flavescência dourada. Este trabalho foi o primeiro relato confirmando a suscetibilidade de videiras à infecção pelo subgrupo 16SrI-B de fitoplasmas, responsável por infecções em uma ampla gama de plantas hospedeiras, em diferentes partes do mundo (Lee et al., 1998). A presença de infecções mistas pelos grupos 16SrI e 16SrIII também foi confirmada em Golan Heights, importante região vitícola de Israel (Orenstein et al., 2001). Na Austrália, também foram detectados fitoplasmas distintos na mesma planta, porém os mesmos não foram relacionados com os grupos de classificação de Lee et al. (1998); neste caso, os fitoplasmas foram relacionados com os diferentes tipos de sintomas exibidos pelas plantas doentes (Constable et al., 2003).

No Brasil, sintomas que se assemelham àqueles encontrados nas videiras cultivadas no continente europeu e na América do Norte têm sido observados em plantas cultivadas em algumas regiões produtoras dos Estados de São Paulo e Paraná. Como as variedades de videira aqui cultivadas são provenientes de materiais europeus ou norteamericanos é possível que nossas culturas estejam infectadas por este tipo de patógeno. A sintomatologia manifestada pela planta de videira infectada por fitoplasmas é muito semelhante àquela provocada por viroses, freqüentes na cultura, como o vírus do 
enrolamento das folhas da videira. Este fato pode estar mascarando a presença do patógeno e dificultando a diagnose da doença.

\subsubsection{Controle}

No controle das doenças causadas por fitoplasmas, as medidas devem estar voltadas sobretudo para a prevenção, principalmente evitando a entrada do patógeno numa área anteriormente livre da doença. A adoção de medidas de controle de doenças baseiam-se principalmente na diagnose precoce e segura. No entanto, a diagnose baseada apenas nos sintomas manifestados pela planta não é totalmente segura para o caso de fitoplasma. Assim, é necessária a detecção do fitoplasma no tecidos da planta para que se tenha uma diagnose confiável.

A obtenção de material propagativo a partir de matrizes livres do patógeno é uma medida complementar de controle, após a chegada do patógeno numa determinada área. No caso da videira, cuidados especiais devem ser tomados, pois é muito comum a importação de matrizes para a produção de mudas, a partir de países onde os amarelos da videira ocorrem com freqüência. Essas matrizes podem estar contaminadas, porém, sem manifestar sintomas. Dessa forma, uma importante medida de controle é manter as plantas matrizes importadas em viveiros de quarentena, por um ou dois anos. Outras medidas de controle recomendadas são o plantio de cultivares que não sejam suscetíveis ao patógeno e o controle de insetos vetores, quando estes são conhecidos, como $S$. titanus,vetor da flavescência dourada (Caudwell,1988). 


\section{MATERIAL E MÉTODOS}

\subsection{Amostras de plantas de videira}

As amostras, na sua grande maioria, foram compostas de folhas obtidas de plantas sintomáticas e assintomáticas cultivadas em campos comerciais. Algumas amostras foram constituídas de ramos dormentes (ano de 2001). As plantas foram amostradas no campo e mantidas em casa de vegetação. Amostra foliar coletada a partir de uma planta assintomática cultivada em local diferente daqueles amostrados serviu como controle negativo.

Os vinhedos amostrados estavam localizados nos municípios de Biritiba MirimSP, Campinas-SP, Jundiaí-SP, Pilar do Sul-SP, Marialva-PR, Londrina-PR e MaringáPR. As plantas amostradas pertenciam às variedades Baco 22A, Benitaka, Brasil, Cabernet Franc, Itália e Maria. As amostragens foram realizadas nos anos de 2000, 2001, 2003 e 2004. A relação de variedades amostradas, procedência e ano de coleta estão apresentadas na Tabela 1. 
Tabela 1. Relação das variedades de videira provenientes de diversas localidades, amostradas em diferentes anos e avaliadas para a presença de fitoplasmas nos tecidos

\begin{tabular}{|c|c|c|c|c|c|}
\hline \multirow[t]{2}{*}{ Variedade } & \multicolumn{4}{|c|}{ Ano de coleta } & \multirow[t]{2}{*}{ Procedência } \\
\hline & 2000 & 2001 & 2003 & 2004 & \\
\hline Itália 08.1210 & $\mathrm{x}$ & $\mathrm{x}$ & $\mathrm{x}$ & $\mathrm{x}$ & Campinas-SP \\
\hline Benitaka & $\mathrm{x}$ & --- & --- & --- & Marialva-PR \\
\hline Itália & $\mathrm{x}$ & --- & --- & --- & Pilar do Sul-SP \\
\hline Itália & $\mathrm{x}$ & --- & --- & --- & Jundiaí-SP \\
\hline Benitaka LD 1587 & $\mathrm{x}$ & $\mathrm{x}$ & $\mathrm{x}$ & $\mathrm{x}$ & Londrina-PR \\
\hline Itália PS 1788 & $\mathrm{x}$ & $\mathrm{x}$ & --- & --- & Pilar do Sul-SP \\
\hline Benitaka 08.3136 & --- & $\mathrm{x}$ & $\mathrm{x}$ & --- & Campinas-SP \\
\hline Cabernet Franc CF 1261 & --- & $\mathrm{x}$ & $\mathrm{x}$ & $\mathrm{x}$ & Campinas-SP \\
\hline Maria LV 1459 & --- & $\mathrm{x}$ & --- & --- & Jundiaí-SP \\
\hline Benitaka 08.3140 & --- & --- & $\mathrm{x}$ & --- & Londrina-PR \\
\hline 110R (BG 1590) & --- & --- & $\mathrm{x}$ & $\mathrm{x}$ & Campinas-SP \\
\hline Seedling Itália (01/96) & --- & --- & $\mathrm{x}$ & $\mathrm{x}$ & Campinas-SP \\
\hline Baco 22A & $\mathrm{x}$ & $\mathrm{x}$ & $\mathrm{x}$ & $\mathrm{x}$ & Campinas-SP \\
\hline Benitaka MV 1774 & --- & --- & $\mathrm{x}$ & --- & Marialva-PR \\
\hline Brasil TP 1780 & --- & $\mathrm{x}$ & $\mathrm{x}$ & $\mathrm{x}$ & Marialva-PR \\
\hline Brasil MV 1781 & --- & --- & $\mathrm{x}$ & --- & Maringá-PR \\
\hline Itália BM 1970 & --- & $\mathrm{x}$ & $\mathrm{x}$ & --- & Biritiba Mirim-SP \\
\hline Seedling Brasil (01/2002) & --- & --- & $\mathrm{x}$ & $\mathrm{x}$ & Campinas-SP \\
\hline Seedling Brasil (03/2002) & --- & --- & $\mathrm{x}$ & --- & Campinas-SP \\
\hline Seedling Brasil (04/2002) & --- & --- & $\mathrm{x}$ & --- & Campinas-SP \\
\hline Brasil (08.3282) & --- & --- & --- & $\mathrm{x}$ & Campinas-SP \\
\hline Brasil (08.3283) & --- & --- & --- & $\mathrm{x}$ & Campinas-SP \\
\hline MV 1775 (08.3278) & --- & --- & --- & $\mathrm{x}$ & Marialva-PR \\
\hline
\end{tabular}




\subsection{Extração de DNA total}

Para a extração do DNA total das amostras foram empregadas duas metodologias, uma delas denominada de extração rápida (Daire et al., 1992) e a outra de extração completa (Lee et al., 1993). Para as folhas, o DNA total foi extraído a partir das nervuras centrais, enquanto para os ramos foi usada a região que continha os vasos de floema. Após a extração, o DNA total foi usado como molde nas reações de PCR.

\subsubsection{Extração rápida}

Cerca de $0,2 \mathrm{~g}$ de material vegetal fresco foi macerado em almofariz de porcelana com o auxílio de nitrogênio líquido. $\mathrm{O}$ macerado foi transferido para microtubos de $1,5 \mathrm{~mL}$, sendo adicionados $800 \mu \mathrm{L}$ de tampão de extração $2 \mathrm{X} \mathrm{CTAB}$ a $60^{\circ} \mathrm{C}$. Os tubos foram incubados em "banho-maria" a $65^{\circ} \mathrm{C}$ por 60 minutos, sendo agitados a cada 10 minutos para homogeneizar a suspensão. A cada tubo foram adicionados $600 \mu \mathrm{L}$ de CIA (clorofórmio/álcool isoamílico 24:1). Centrifugou-se o lisado por 15 minutos a 14.000rpm. A fase superior (aquosa) foi retirada e transferida para outro tubo de $1,5 \mathrm{~mL}$ no qual foram adicionados $540 \mu \mathrm{L}$ de isopropanol gelado. Os tubos foram mantidos por uma noite a $-20^{\circ} \mathrm{C}$. No dia seguinte, fez-se a centrifugação por 10 minutos a $14.000 \mathrm{rpm}$ e descartou-se o sobrenadante. Ao precipitado foi adicionado $1 \mathrm{~mL}$ de etanol $80 \%$ e incubou-se por um período de 10 minutos. Em seguida, o etanol foi descartado e esta operação foi repetida mais uma vez. Foram adicionados $500 \mu \mathrm{L}$ de $\mathrm{NaCl} 1 \mathrm{M}$ e procedeuse à incubação por 30 a 60 minutos a $4^{\circ} \mathrm{C}$. Novamente fez-se centrifugação por 14.000rpm por 10 minutos. O precipitado foi lavado com $1 \mathrm{~mL}$ de etanol $80 \%$ por 10 minutos e a operação foi realizada mais uma vez. O etanol foi descartado e os tubos foram mantidos abertos e invertidos sobre papel toalha para secar o precipitado. Após a secagem, o precipitado foi ressuspendido em $100 \mu \mathrm{L}$ de água deionizada ou solução tampão $1 \times$ TE e armazenado a $-20^{\circ} \mathrm{C}$.

Para o preparo do tampão de extração $2 \mathrm{X}$ CTAB foi seguido o seguinte protocolo: Foram pesados $2 \mathrm{~g}$ de CTAB; 8,18g de NaCl; 0,74g de EDTA; 1,57g de Tris$\mathrm{HCl}$ e 1,0g de PVP. Os materiais foram dissolvidos em água deionizada, completando o 
volume para $100 \mathrm{~mL}$. O pH foi acertado para 8,0 . No momento de uso do tampão, acrescentou-se $0,2 \mathrm{~mL}$ de mercaptanol.

\subsubsection{Extração completa}

Cerca de $2 \mathrm{~g}$ de material vegetal fresco foi macerado em nitrogênio líquido. Adicionou-se um volume de $14 \mathrm{~mL}$ de solução tampão de extração I e o material foi transferido para tubos de vidro de $30 \mathrm{~mL}$. A mistura foi centrifugada a $13.000 \mathrm{rpm}$ por 20 minutos. O sobrenadante foi descartado e o precipitado ressuspendido em $8 \mathrm{~mL}$ de solução tampão de extração II. Volumes de $160 \mu \mathrm{L}$ de proteinase K e $880 \mu \mathrm{L}$ de sarkosyl $10 \%$ foram adicionados e os tubos foram mantidos por 2 horas a $55^{\circ} \mathrm{C}$, em "banhomaria". O lisado foi centrifugado a $8.000 \mathrm{rpm}$ durante 10 minutos e o sobrenadante foi transferido para outros tubos sendo adicionados $5,5 \mathrm{~mL}$ de isopropanol. $\mathrm{O}$ material foi mantido a $-20^{\circ} \mathrm{C}$ por uma noite. No dia seguinte, o material foi centrifugado por 15 minutos a $8.000 \mathrm{rpm}$. O sobrenadante foi descartado e o precipitado ressuspendido em uma mistura de $3 \mathrm{~mL}$ de solução tampão $1 \mathrm{X}$ TE, $75 \mu \mathrm{L}$ de $\operatorname{SDS} 20 \%$ e $60 \mu \mathrm{L}$ de proteinase K. Os tubos foram mantidos em "banho-maria" a $37^{\circ} \mathrm{C}$ por 1 hora e, em seguida, foram adicionados em cada tubo $525 \mu \mathrm{L}$ de $\mathrm{NaCl} 5 \mathrm{M}$ e $420 \mu \mathrm{L}$ de $\mathrm{CTAB} / \mathrm{NaCl}$, sendo feita uma nova incubação por 10 minutos a $65^{\circ} \mathrm{C}$. Alíquota de $4 \mathrm{~mL}$ de CIA (clorofórmio/álcool isoamílico 24:1) foi adicionada à mistura, sendo a mesma centrifugada a $6.000 \mathrm{rpm}$ por 5 minutos. A fase aquosa foi removida para novos tubos, sendo acrescentados $4 \mathrm{~mL}$ de CIA. Nova centrifugação foi conduzida a $6.000 \mathrm{rpm}$ por 5 minutos, salvando a fase aquosa para novos tubos, nos quais foram adicionados $2 \mathrm{~mL}$ de fenol e $2 \mathrm{~mL}$ de CIA. A mistura foi centrifugada a $6.000 \mathrm{rpm}$ por 5 minutos. A fase aquosa foi transferida para novos tubos, acrescida de $4 \mathrm{~mL}$ de CIA. Após centrifugação a 6.000rpm por 5 minutos, a fase aquosa foi transferida para novos tubos e acrescida de $2,5 \mathrm{~mL}$ de isopropanol. Os tubos foram mantidos a $-20^{\circ} \mathrm{C}$ por uma noite para ocorrer a precipitação dos ácidos nucléicos. Após esse período, o material foi centrifugado a 10.000rpm por 10 minutos. O sobrenadante foi descartado e ao precipitado foram adicionados $8 \mathrm{~mL}$ de etanol $70 \%$, mantendo-se a mistura a $4^{\circ} \mathrm{C}$ por 30 minutos. Fez-se nova centrifugação a $6.000 \mathrm{rpm}$ por 10 minutos, descartando o sobrenadante. Os tubos 
foram invertidos sobre papel toalha e, após estarem devidamente secos, os precipitados foram ressuspendidos em 200-300 $\mu \mathrm{L}$ de solução tampão TE 1X. Fez-se a transferência da suspensão para microtubos e o DNA total extraído foi armazenado a $-20^{\circ} \mathrm{C}$.

Segue abaixo as especificações sobre o preparo das soluções tampão usadas neste protocolo:

- Tampão de extração I: Foram pesados 5,42g de $\mathrm{K}_{2} \mathrm{HPO}_{4}-3 \mathrm{H}_{2} \mathrm{O}, 1,02 \mathrm{~g}$ de $\mathrm{K}_{2} \mathrm{HPO}_{4}$, $25 \mathrm{~g}$ de sucrose, $0,375 \mathrm{~g}$ de BSA e 5,0g de PVP-10. Os materiais foram dissolvidos em agitador magnético, completando o volume com água destilada autoclavada para $250 \mathrm{~mL}$. O tampão foi mantido em geladeira, a $4^{\circ} \mathrm{C}$. Antes de começar a extração, adicionou-se $0,53 \mathrm{~g}$ de ácido ascórbico para cada $100 \mathrm{~mL}$ de tampão, agitando a mistura e por último, acertou-se o $\mathrm{pH}$ para 7,6.

- Tampão de extração II: Foram pesados $6 \mathrm{~g}$ de Tris-base, 7,3g de $\mathrm{NaCl}$ e 18,6g de EDTA. Dissolveu-se a mistura em agitador magnético, completando o volume com água destilada para 500mL. Acertou-se o pH para 8,0 e o tampão foi autoclavado.

- Tampão TE 100X: Foram pesados 6,05g de Tris-base e 1,86g de EDTA. Dissolveu-se a mistura em agitador magnético e completou-se o volume com água destilada para 50mL. Acertou-se o pH para 8,0 com $\mathrm{HCl}$ concentrado e o tampão foi autoclavado.

\subsection{Purificação do DNA}

Após a extração, parte do DNA total extraído foi purificado, com o objetivo de aumentar a sensibilidade de detecção nos testes de PCR. Para isto foi empregado um conjunto de reagentes pertencentes ao "Gene Clean Kit - BIO 101" (Vista/CA). O procedimento para a purificação seguiu as instruções do fabricante.

\subsection{Detecção de fitoplasmas por PCR}

O DNA total de cada amostra, purificado ou não, foi diluído nas proporções de 1:5, 1:10, 1:20, 1:50 e 1:100 em água destilada deionizada ('miliq'). Para a detecção de fitoplasmas foram empregados os iniciadores ("primers") universais R16mF2/mR1, P1/P7 e R16F2n/R2, em PCR duplo. Na primeira reação, foi usado o par R16mF1/mR2 ou P1/P7, sendo o produto amplificado diluído em água deionizada na proporção 1:50 e 
usado como molde para a segunda reação com o par R16F2n/R2. Esses últimos iniciadores amplificam uma determinada seqüência de $1,2 \mathrm{~Kb}$ do DNA genômico dos fitoplasmas, correspondente ao $16 \mathrm{~S}$ rDNA.

Cada reação de PCR foi processada utilizando um volume final de $25 \mu \mathrm{L}$, contendo os seguintes componentes: $1 \mu \mathrm{L}$ de extrato de DNA diluído de cada amostra de videira; $18,3 \mu \mathrm{L}$ de água destilada deionizada; $0,5 \mu \mathrm{L}$ de cada iniciador (solução 20 $\mathrm{pmol} / \mu \mathrm{L}$ ); $2 \mu \mathrm{L}$ de uma mistura de deoxinucleotídeo trifosfato (solução 2,5 mM de cada deoxinucleotídeo); $2,5 \mu \mathrm{L}$ de solução tampão 10X PCR e $0,17 \mu \mathrm{L}$ de Amplitaq 5U/ $\mu \mathrm{L}$.

Como controles negativos foram usados o DNA extraído de planta assintomática de videira e água destilada deionizada autoclavada. Os padrões positivos foram representados pelos DNA extraído de plantas de milho e de chuchu comprovadamente infectadas por fitoplasma. O padrão de peso molecular utilizado foi $1 \mathrm{~Kb}$ ladder.

O termociclador foi programado para 35 ciclos, compreendendo as etapas: 1 minuto a $94^{\circ} \mathrm{C}$ para a etapa de desnaturação do ácido nucléico, 2 minutos a $50^{\circ} \mathrm{C}$ para o anelamento e 3 minutos a $72^{\circ} \mathrm{C}$ para a fase de extensão do "primer". Um tempo adicional de 1 minuto e de 7 minutos foram permitidos para a etapa de desnaturação do primeiro ciclo e para a etapa de extensão do último ciclo, respectivamente.

As seqüências dos iniciadores utilizados encontram-se descritas abaixo:

R16 P1 - 5'AAG AGT TTG ATC CTG GCT CAG GAT T 3' (Deng \& Hiruki, 1991)

R16 P7- 5'CGT CCT TCA TCG GCT CTT 3' (Smart et al., 1996)

R16 mF2 - 5'CAT GCA AGT CGA ACG A 3' (Gundersen \& Lee, 1996)

R16 mR1- 5'CTT AAC CCC AAT CAT CGA C 3' (Gundersen \& Lee, 1996)

R16 F2n- 5'GAA ACG ACT GCT AAG ACT GG 3' (Gundersen \& Lee, 1996)

R16 R2- 5'TGA CGG GCG GTG TGT ACA AAC CCC G 3'(Gundersen \& Lee, 1996)

\subsection{Identificação de fitoplasma por PCR}

Para as amostras positivas de videira, nas quais ocorreu a detecção de fitoplasmas, foram conduzidos novos testes de PCR empregando-se, agora, os iniciadores específicos, os quais permitem a identificação de fitoplasmas pertencentes aos grupos 16SrI, 16SrIII e $16 \mathrm{SrV}$. 
Os produtos de PCR obtidos com os iniciadores R16 F2n/R2 foram diluídos em água deionizada na proporção 1:20 e submetidos à re-amplificação usando-se os iniciadores R16(I)F1/R1, R16(III)F2/R1 e R16(V)F1/R1. As condições de PCR foram as mesmas descritas no item 3.4. Como padrão positivo para o grupo $16 \mathrm{SrI}$ foi usado extrato de planta de milho infectada pelo fitoplasma do enfezamento vermelho, representante do grupo 16SrI. Para o grupo 16SrIII, foi usada uma amostra de chuchu infectada com o fitoplasma do superbrotamento, representante do grupo 16SrIII. Como padrão para o grupo $16 \mathrm{SrV}$, extrato de planta de crotalária infectada pelo fitoplasma do superbrotamento, representante do grupo $16 \mathrm{SrV}$. O padrão negativo foi representado pela água.

A seqüência dos iniciadores específicos utilizados segue abaixo:

*Iniciadores específicos (Lee et al., 1994):

R16(I)F1- 5'TAA AAG ACC TAG CAA TAG G 3'

R16(I)R1- 5'CAA TCC GAA CTG AGA CTG T 3'

R16 (III)F2- 5'AAG AGT GGA AAA ACT CCC 3'

R16(III)R1- TCC GAA CTG AGA TTG A 3'

R16(V)F1- TTA AAA AGA CTT CTT CGG 3'

R16(V)R1- TTC AAT CCG TAC TGA GAC TAC C 3'

\subsection{Eletroforese em gel de agarose}

Os produtos da re-amplificação com os iniciadores universais e com os iniciadores específicos foram analisados por eletroforese em gel de agarose $1 \%$ e tampão TAE 1X. A corrida eletroforética se deu à voltagem constante de $65 \mathrm{~V}$ por 90 minutos. A seguir, o gel foi imerso em uma solução de brometo de etídio por 10 minutos, para coloração, com posterior lavagem em água destilada por 10 minutos. As bandas de DNA foram visualizadas em um transiluminador de luz ultravioleta.

\subsection{Identificação dos fitoplasmas por análise de RFLP}

As seqüências amplificadas por duplo PCR com o par R16 F2n/R2 foram analisadas por RFLP através do uso de diversas enzimas de restrição. Uma alíquota de 
$5 \mu \mathrm{L}$ de cada produto de PCR foi digerida, separadamente, com as enzimas AluI, KpnI, MseI, RsaI, HhaI, HpaII, MboI e Hinf I segundo as instruções dos fabricantes, durante um período de 30 horas a $36^{\circ} \mathrm{C}$. Os produtos da digestão enzimática foram separados por eletroforese em gel de poliacrilamida 5\%, usando tampão TBE 1X. A corrida eletroforética foi processada a $220 \mathrm{~V}$ por $5 \mathrm{~min}$ e $150 \mathrm{~V}$ por $50 \mathrm{~min}$. O gel foi colorido com brometo de etídio e os fragmentos de DNA visualizados em um transiluminador de luz ultravioleta.

Os fragmentos correspondentes ao $16 \mathrm{~S}$ rDNA dos fitoplasmas do enfezamento vermelho do milho e do superbrotamento do chuchu foram usados como padrões para o grupo16SrI e 16SrIII, respectivamente, nas análises de RFLP. Como marcador de peso molecular foi usado Phi X174RFHaeIII.

O perfil eletroforético obtido para cada fitoplasma foi comparado com padrões existentes na literatura, para a respectiva enzima de restrição (Lee et al., 1998). Desta forma, os fitoplasmas encontrados nas plantas de videira foram classificados, de acordo com os grupos atualmente considerados para esta finalidade.

Seguem descritas as enzimas de restrição e seus respectivos sítios de corte:

- $\quad$ Alu I: AG $\nabla$ CT

- Kpn I: GGTAC $\boldsymbol{\nabla C}$

- $\quad$ Mse I: T $\mathbf{\nabla}$ TAA

- $\quad$ Rsa I: GT $\nabla \mathrm{AC}$

- Hha I: GCG $\nabla \mathrm{C}$

- Hpa II: C $\boldsymbol{\nabla}$ CGG

- $\quad$ Mbo I: $\nabla$ GATC

- Hinf I: G $\nabla$ ANTC 


\section{RESULTADOS E DISCUSSÃO}

\subsection{Detecção através de duplo PCR}

Os sintomas presentes nas plantas suspeitas de infecção por fitoplasma eram semelhantes àqueles relatados em outras regiões do mundo. As folhas mostravam enrolamento marginal, amarelecimento ou avermelhamento do limbo e nervuras, seguido de necrose e rachaduras nas nervuras principais.

No total, foram coletadas e submetidas aos testes de PCR amostras de 23 plantas sintomáticas e assintomáticas, sendo que fitoplasmas foram detectados em 10 destas plantas (Tabela 2). Especificamente para a amostra identificada com o número 10 (variedade Brasil 1780 coletada em Marialva-PR em 2004), fitoplasmas foram detectados em amostras de folhas jovens e adultas. Neste caso, as sub-amostras foram identificadas como 10A (folha adulta) e 10B (folha jovem).

Os fragmentos do 16S rDNA dos fitoplasmas foram amplificados pelos pares de iniciadores R16 mF2/R1 (amostras coletadas em 2000) ou P1/P7 (amostras coletadas em 2001, 2003 e 2004) e re-amplificados sempre pelo par R16 F2n/R2. Os materiais positivos para a presença de fitoplasmas foram identificados pela visualização de bandas de aproximadamente $1,2 \mathrm{~Kb}$, no gel de agarose, após a eletroforese. Os padrões positivos de milho e chuchu também apresentaram bandas típicas de $1,2 \mathrm{~Kb}$, enquanto nenhuma amplificação ocorreu nos padrões negativos, representados pela planta de videira assintomática e pela água deionizada (Figuras 1 e 2).

A maioria das plantas usadas nos testes de detecção por PCR foram amostradas em anos diversos, porém, resultados positivos para a presença de fitoplasmas só foram 
obtidos, em mais de um ano, para três plantas (Benitaka LD 1587, Londrina-PR, Itália PS 1788, Pilar do Sul-SP e Seedling Brasil 01/2002, Campinas-SP), como pode ser visto na Tabela 2.

O resultado negativo obtido em determinados anos para plantas infectadas pode ser atribuído a fatores diversos, como à época de amostragem em relação ao período fenológico da planta, a presença de substâncias inibidoras à reação de PCR encontradas na planta, à distribuição desuniforme do patógeno ou a presença do patógeno em baixa concentração nos tecidos da planta.

Tabela 2. Relação das plantas de videira nas quais foram detectados fitoplasmas através de testes de PCR

\begin{tabular}{cccc}
\hline Identificação & Variedade & Local de Coleta & Ano de Coleta \\
\hline 1 & Itália & Jundiá́-SP & 2000 \\
2 & Benitaka LD1587 & Londrina-PR & $2000 / 2001$ \\
3 & Itália PS 1788 & Pilar do Sul-SP & $2000 / 2001$ \\
4 & Benitaka & Marialva-PR & 2000 \\
5 & Itália 08.1210 & Campinas-SP & 2000 \\
6 & Benitaka 08.3136 & Campinas-SP & 2001 \\
7 & Cabernet Franc & Campinas-SP & 2001 \\
& CF1261 & & \\
8 & Maria LV1459 & Jundiaí-SP & 2001 \\
9 & Seedling Brasil & Campinas-SP & $2003 / 2004$ \\
& $(01 / 2002)$ & & 2004 \\
$10 \mathrm{~A}$ & Brasil 1780 & Marialva-PR & 2004 \\
10B & Brasil 1780 & Marialva-PR &
\end{tabular}

A videira é uma planta de clima temperado, que apresenta um período de dormência durante seu ciclo vegetativo. Trabalhos conduzidos com videira e algumas 
outras plantas lenhosas que apresentam período de dormência, como por exemplo a pêra, têm apontado dificuldades na detecção do patógeno, decorrentes da distribuição e concentração desuniformes do patógeno na planta, em função do seu estádio fenológico (Chapa et al., 2003). Em estudos feitos para avaliar o efeito do estádio vegetativo da videira sobre a detecção de fitoplasmas, Del Serrone \& Barba (1996) demonstraram que existem diferenças em função do estádio fenológico e das partes da planta amostradas. Em trabalho conduzido ao longo de alguns anos na Austrália, constatou-se que fitoplasmas nem sempre foram detectados a partir de um mesmo tipo de tecido de plantas de videira ou a partir de um mesmo período de amostragem (Constable et al., 2003). Estes resultados sugeriram que os fitoplasmas persistem nas plantas de ano para ano, sobrevivendo e se multiplicando mesmo durante o período de dormência da planta. Outros trabalhos realizados com fitoplasmas em videira e outras plantas lenhosas relatam que apesar da sensibilidade, a diagnose através da técnica de PCR pode ser confundida pela distribuição irregular e baixa concentração do fitoplasma na planta (Daire et al.,1992) e também porque a presença de inibidores da reação de PCR podem variar ao longo do ano (John, 1992; Green et al., 1999).

No presente trabalho, pode-se atribuir a não detecção de fitoplasmas em videiras infectadas a estes diversos fatores, com base nos trabalhos anteriormente relatados (Daire et al.,1992; John, 1992; Del Serrone \& Barba, 1996; Green et al., 1999; Chapa et al., 2003; Constable et al., 2003). As amostragens não foram sempre realizadas na mesma época do ano, portanto, foram feitas em diferentes estádios fenológicos da planta. As amostras coletadas constituíram-se quase que na sua maioria de folhas, ou seja, foi analisado somente um tipo de tecido da planta. A concentração do patógeno neste tipo de tecido vegetal poderia estar baixa nas épocas em que foi coletada a amostra, dificultando a extração do patógeno. Ainda, a concentração de compostos inibidores, como por exemplo os compostos fenólicos, produzidos pela videira poderiam estar presentes em concentrações altas, em função do estádio fenológico ou do tecido amostrado, o que poderia impedir a amplificação do fragmento alvo dos fitoplasmas nas reações de PCR. 
Um resultado interessante foi a detecção de fitoplasmas em material obtido a partir de sementes de videira (Seedling Brasil 01/2002, Campinas-SP), em dois anos consecutivos (2003 e 2004). De acordo com a literatura, até o momento, não existem evidências substanciais que indiquem a transmissão de fitoplasmas por sementes (Lee et al., 2000). A presença de fitoplasmas em material de videira proveniente de semente talvez possa ser explicada ou por infecção ocorrida em casa de vegetação ou pela própria passagem do patógeno via semente. Esta última possibilidade deverá ser objeto de futuras investigações.

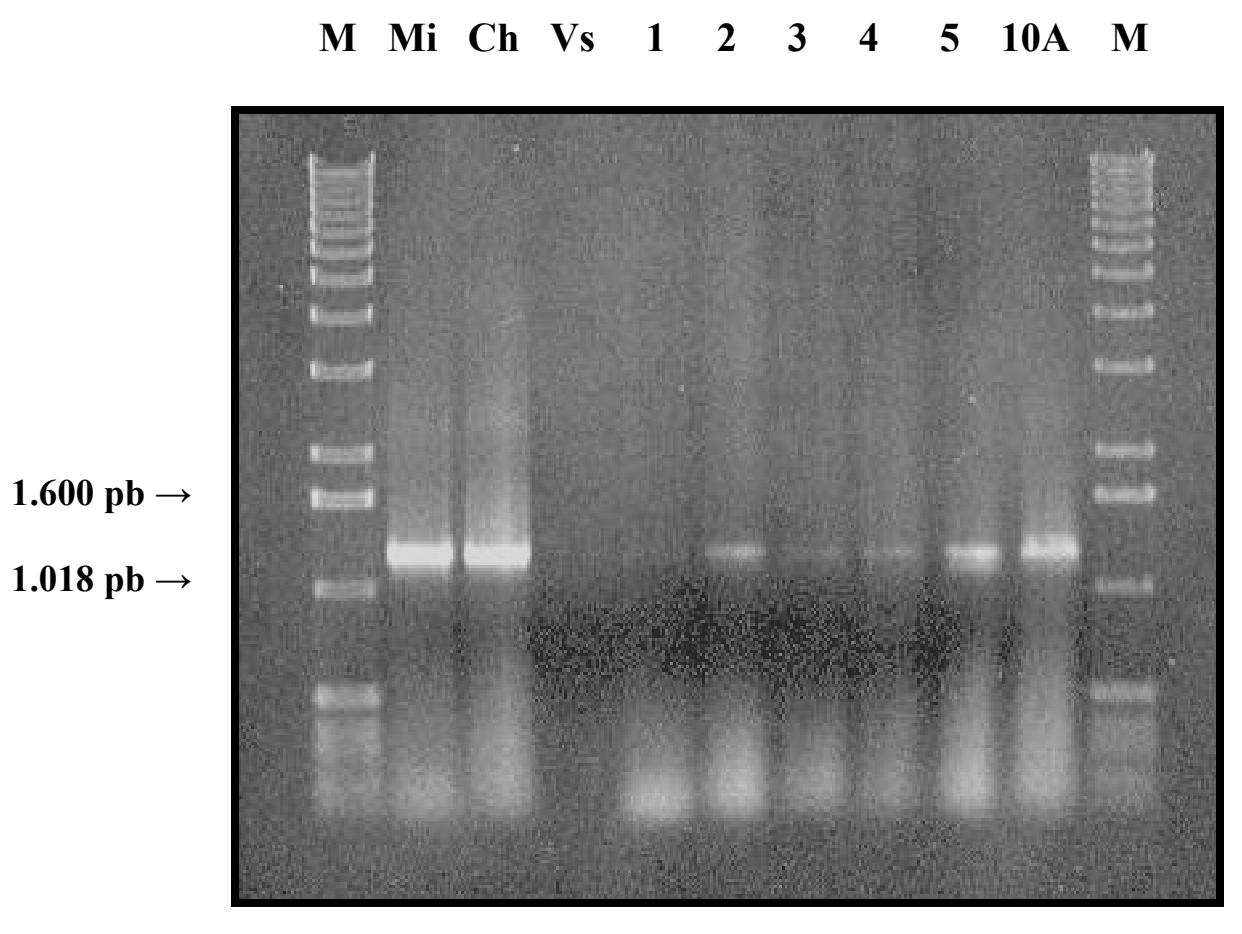

Figura 1- Amostras de videira coletadas em 2000 e 2004 positivas para a presença de fitoplasmas, detectados por duplo PCR. $\mathrm{M}=$ Marcador molecular $1 \mathrm{~Kb}$ ladder; $\mathrm{Mi}=$ padrão positivo de milho; $\mathrm{Ch}=$ padrão positivo de chuchu; $\mathrm{Vs}=$ padrão negativo videira sadia; $1=$ Itália, Jundaí-SP; $2=$ Benitaka LD1587, LondrinaPR; 3= Itália PS1788, Pilar do Sul-SP; 4= Benitaka, Marialva-PR; 5= Itália 08.1210, Campinas-SP;10A= Brasil1780, Marialva-PR 


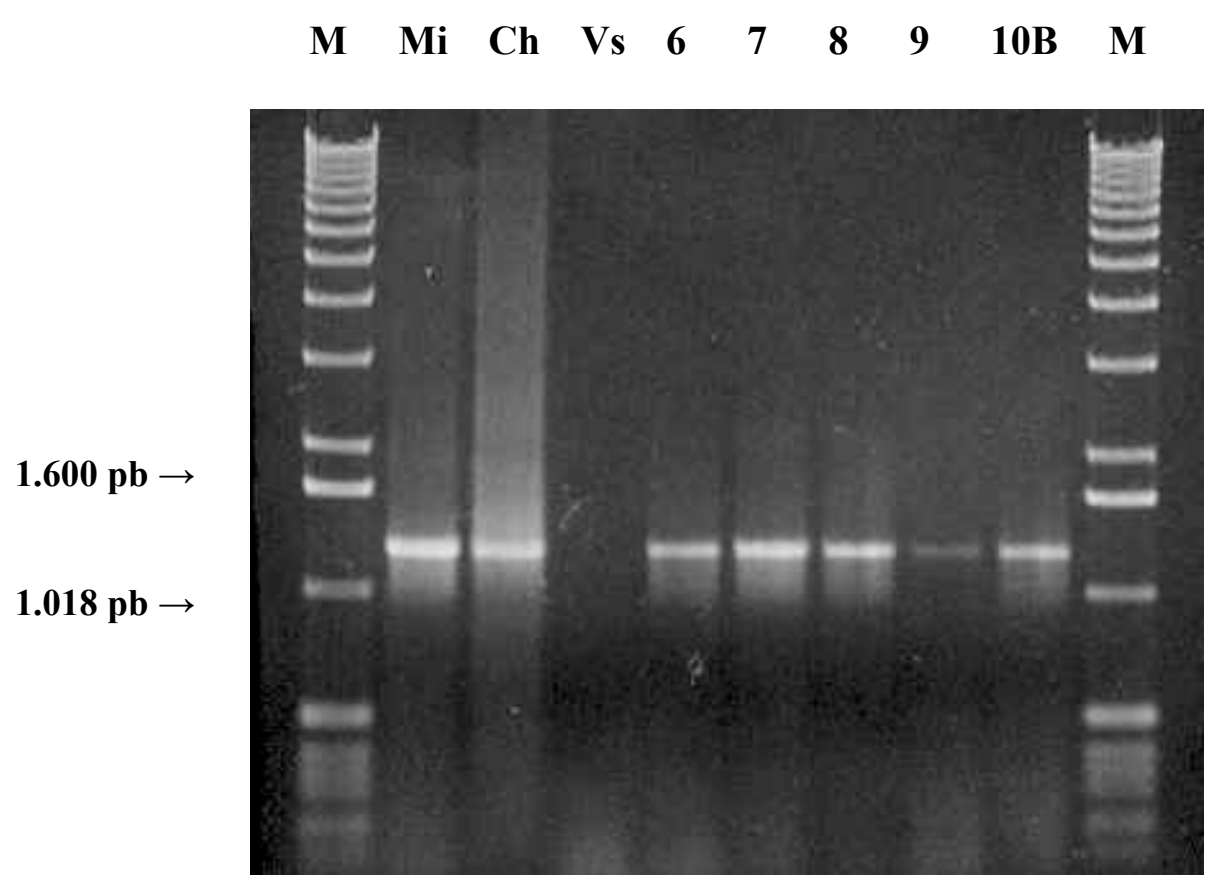

Figura 2- Amostras de videira coletadas em 2001, 2003 e 2004 positivas para a presença de fitoplasmas, detectados por duplo PCR. M= Marcador molecular $1 \mathrm{~Kb}$ ladder; $\mathrm{Mi}=$ padrão positivo de milho; $\mathrm{Ch}=$ padrão positivo de chuchu; $\mathrm{Vs}=$ padrão negativo videira sadia; $6=$ Benitaka 08.3136, Campinas-SP; 7= Cabernet Franc CF1261, Campinas-SP; 8= Maria LV1459, Jundiaí-SP; 9= Seedling Brasil, Campinas-SP; 10B= Brasil 1780, Marialva-PR

\subsection{Identificação de fitoplasmas por PCR}

Após a detecção de fitoplasmas em 10 amostras de videira, os produtos da segunda reação de PCR de todas estas amostras foram diluídos na proporção de 1:20 e submetidos a um novo teste de PCR. Os iniciadores utilizados foram aqueles específicos para identificação de fitoplasmas pertencentes aos grupos $16 \mathrm{SrI}$, 16SrIII e 16SrV. Os resultados estão expressos na Tabela 3. Nas amostras 6, 7,8 e 9 foram amplificados fragmentos de DNA pelos iniciadores específicos do grupo 16SrI (Figura 3). Nas amostras 1, 2, 3, 4 e 5 ocorreram amplificações com o uso dos iniciadores específicos para fitoplasmas do grupo 16SrIII (Figura 6). Para a amostra 10 foram amplificados 
fragmentos de DNA genômico tanto de fitoplasmas representantes de grupo 16SrI como 16SrIII (Figuras 3 e 6).

Tabela 3. Identificação de fitoplasmas presentes em amostras de videira, através de PCR usando iniciadores para grupos específicos

\begin{tabular}{|c|c|c|c|c|}
\hline Identificação & Variedade & $\begin{array}{l}\text { Local de } \\
\text { Coleta }\end{array}$ & $\begin{array}{l}\text { Ano de } \\
\text { Coleta }\end{array}$ & $\begin{array}{c}\text { Grupo } \\
\text { Específico }\end{array}$ \\
\hline 1 & Itália & Jundiaí-SP & 2000 & $16 \mathrm{SrIII}$ \\
\hline 2 & $\begin{array}{l}\text { Benitaka } \\
\text { LD1587 }\end{array}$ & Londrina-PR & 2000 & 16SrIII \\
\hline 3 & Itália PS 1788 & Pilar do Sul-SP & 2000 & 16SrIII \\
\hline 4 & Benitaka & Marialva-PR & 2000 & $16 \mathrm{SrIII}$ \\
\hline 5 & Itália 08.1210 & Campinas-SP & 2000 & $16 \mathrm{SrIII}$ \\
\hline 6 & $\begin{array}{c}\text { Benitaka } \\
08.3136\end{array}$ & Campinas-SP & 2001 & $16 \mathrm{SrI}$ \\
\hline 7 & $\begin{array}{l}\text { Cabernet Franc } \\
\text { CF1261 }\end{array}$ & Campinas-SP & 2001 & $16 \mathrm{SrI}$ \\
\hline 8 & Maria LV1459 & Jundiaí-SP & 2001 & $16 \mathrm{SrI}$ \\
\hline 9 & Seedling Brasil & Campinas-SP & 2003 & $16 \mathrm{SrI}$ \\
\hline $10 \mathrm{~A}$ & Brasil 1780 & Marialva-PR & 2004 & $16 \mathrm{SrIII}$ \\
\hline $10 \mathrm{~B}$ & Brasil 1780 & Marialva-PR & 2004 & $16 \mathrm{SrI}$ \\
\hline
\end{tabular}

Os fragmentos amplificados pelos iniciadores R16(I)F1/R1, específicos para a identificação de fitoplasmas do grupo 16SrI, possuíam cerca de 1,1Kb (Figuras 3 e 5), enquanto que os fragmentos amplificados pelos iniciadores R16(III)F2/R1, específicos para fitoplasmas do grupo 16SrIII, possuíam cerca de 0,8Kb (Figuras 4 e 6). A amplificação destes dois tipos de fragmentos genômicos com os pares de iniciadores para grupos específicos correspondem aos descritos por Lee et al. (1994) para os respectivos grupos e confirmam a presença de fitoplasmas dos grupos $16 \mathrm{SrI}$ e $16 \mathrm{SrIII}$ 
nas plantas de videira amostradas. Para as amostras de milho e de chuchu, usadas como padrões, fragmentos da ordem de $1,1 \mathrm{~Kb}$ e de $0,8 \mathrm{~Kb}$ foram amplificados, respectivamente, pelos iniciadores específicos para fitoplasmas dos grupos 16SrI e 16SrIII, confirmando a validade do teste de PCR para a identificação dos fitoplasmas ocorrentes em videira.

Fitoplasmas pertencentes ao grupo $16 \mathrm{SrV}$ não foram detectados nas plantas de videira amostradas, pois, não ocorreu amplificação quando os iniciadores específicos para a identificação de fitoplasmas deste grupo foram empregados nas reações de PCR duplo (dados não apresentados). PCR utilizando iniciadores específicos para o grupo $16 \mathrm{SrV}$ foi conduzido pelo fato do agente causal da flavescência dourada ser um fitoplasma pertencente a este grupo, como demonstrado em outros trabalhos (Prince et al., 1993; Daire et al., 1997; Lee et al., 1998; Martini \& Murari, 1999; Davis \& Dally, 2001). Assim sendo, caso alguma das amostras se apresentasse positiva para estes iniciadores, estaria evidenciada a presença da flavescência dourada em nossas condições.

Os testes de duplo PCR usando os iniciadores para grupos específicos foram bastante úteis, pois além de possibilitarem a identificação de fitoplasmas detectados na videira, permitiram demonstrar a ocorrência de fitoplasmas pertencentes a diferentes grupos de classificação em um mesmo hospedeiro. Isto caracterizou a chamada infecção mista, a qual, no presente caso, foi promovida por fitoplasmas afiliados aos grupos $16 \mathrm{SrI}$ e 16SrIII, presentes na variedade Brasil 1780, coletada em Marialva-SP. Lee et al. (2000) relataram que uma determinada espécie de planta ou inseto vetor pode, potencialmente, compartilhar dois ou mais tipos distintos de fitoplasmas e que infecções mistas de fitoplasmas em uma única planta são evidentes na natureza. As infecções mistas já foram relatadas em videiras por Alma et al. (1996) na Itália, por Orenstein et al. (2001) em Israel e por Constable et al. (2003), na Austrália. Na Itália, foram identificados fitoplasmas pertencentes aos grupos $16 \mathrm{SrI}$ e $16 \mathrm{SrV}$, enquanto em Israel foi identificada infecção mista, na qual estavam presentes representantes dos grupos $16 \mathrm{SrI} \mathrm{e}$ 16SrIII. Este tipo de trabalho tem revelado que a planta é geralmente infectada por um fitoplasma predominante e por um ou mais fitoplasmas que estão presentes em baixa concentração. 

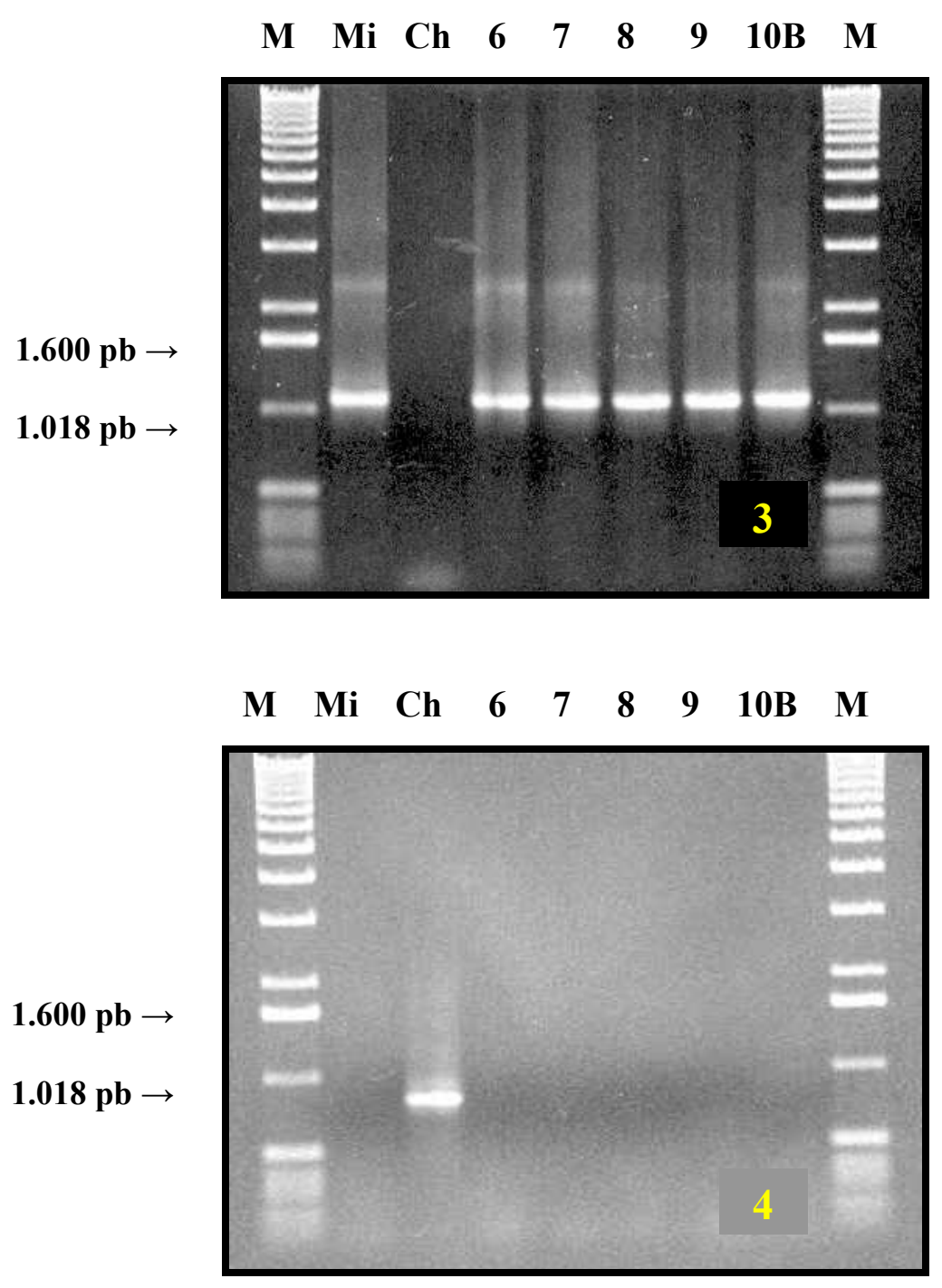

Figuras 3 e 4- Identificação de fitoplasmas presentes em amostras de videira, através de PCR usando iniciadores específicos para o grupo 16SrI e 16SrIII, respectivamente. $\mathrm{M}=$ marcador molecular $1 \mathrm{~Kb}$ ladder; $\mathrm{Mi}=$ amostra de milho (16SrI); $\mathrm{Ch}=$ amostra de chuchu (16SrIII); $6=$ Benitaka 08.3136, Campinas-SP; 7= Cabernet Franc CF1261, Campinas-SP; 8= Maria LV1459, Jundiaí-SP; 9= Seedling Brasil, Campinas-SP; 10B= Brasil 1780, Marialva-PR 

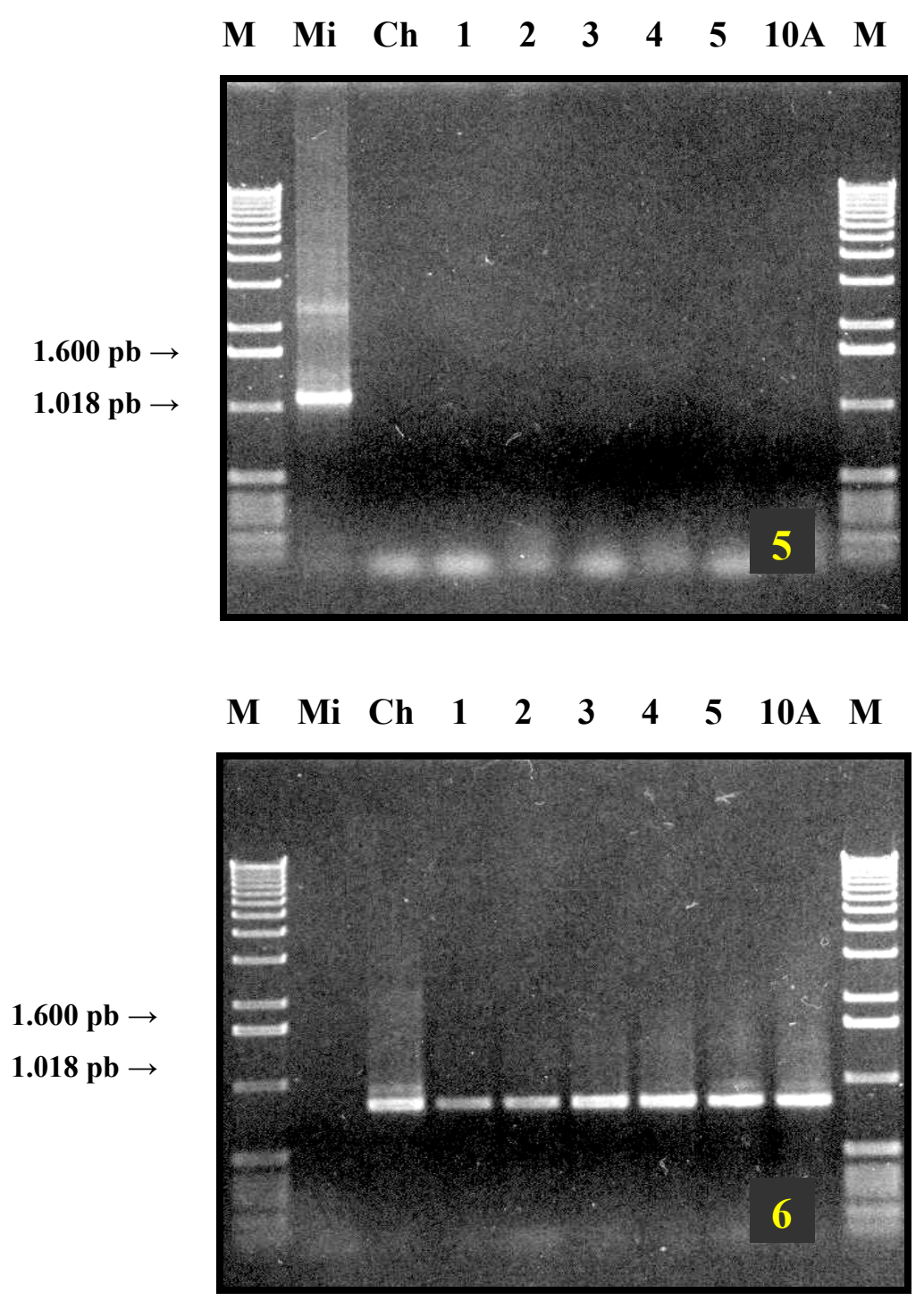

Figuras 5 e 6- Identificação de fitoplasmas presentes em amostras de videira, através de PCR usando iniciadores específicos para o grupo 16SrI e 16SrIII, respectivamente. $\mathrm{M}=$ marcador molecular $1 \mathrm{~Kb}$ ladder; $\mathrm{Mi}=$ amostra de milho (16SrI); $\mathrm{Ch}=$ amostra de chuchu (16SrIII); 1= Itália, Jundaí-SP; 2= Benitaka LD1587, Londrina-PR; 3= Itália PS1788, Pilar do Sul-SP; 4= Benitaka, Marialva-PR; 5= Itália 08.1210, Campinas-SP; 10A= Brasil 1780, Marialva-PR 


\subsection{Identificação de fitoplasma através da análise de RFLP}

As análises de RFLP foram realizadas com os isolados de fitoplasmas presentes nas amostras identificadas pelos números 6, 7, 8, 9 e 10B, sendo estes fitoplasmas identificados como membros do grupo 16SrI, através de PCR conduzido com iniciadores específicos.

Os cinco isolados de fitoplasmas analisados por RFLP apresentaram perfis eletroforéticos idênticos para cada uma das enzimas de restrição, sendo, portanto, indistigüíveis entre si. Estes cinco isolados também mostraram, para cada endonuclease, padrões de restrição idênticos ao isolado do fitoplasma do enfezamento vermelho do milho, típico representante do grupo $16 \mathrm{SrI}$, usado como padrão.

A enzima KpnI gerou um perfil típico para fitoplasmas do grupo 16SrI, permitindo diferenciar os fitoplasmas ocorrentes na videira dos fitoplasmas pertencentes aos demais grupos de classificação, exceção feita ao representante do grupo 16SrXII (Figura 7). Os perfis obtidos com a enzima MseI, no entanto, demonstraram que os isolados da videira são afiliados ao grupo 16SrI e não ao grupo 16SrXII (Figura 12). Para as enzimas MseI, AluI e RsaI, os perfis resultantes da digestão enzimática dos produtos amplificados pelo PCR duplo demonstraram que os cinco isolados presentes em videira são afiliados ao grupo 16SrI (Figuras 12, 13 e 8, respectivamente) de acordo com os padrões considerados por Lee et al. (1998). O emprego das endonucleases HpaII, HinfI e MboI confirmaram os resultados obtidos com as demais enzimas de restrição (Figuras 9, 10 e 11). A classificação destes fitoplasmas ao nível de subgrupo foi feita com base nos perfis eletroforéticos obtidos para as endonucleases MseI e HhaI. A comparação dos perfis gerados por estas duas enzimas para os fitoplasmas encontrados nas amostras de videira com aqueles relatados pela literatura (Lee et al., 1998) revelou que os cinco isolados podem ser classificados como pertencentes ao subgrupo B (Figuras 12 e 14). As análises de RFLP, portanto, possibilitaram confirmar a identificação molecular conduzida com os iniciadores específicos usados em PCR duplo.

A associação de fitoplasmas do grupo $16 \mathrm{SrI}$ com os amarelos da videira, como demonstrado no presente trabalho, também tem sido relatada em vinhedos localizados em países como os Estados Unidos (Prince et al., 1993; Davis et al., 1998), Israel 
(Orenstein et al., 2001) e Itália (Alma et al.,1996). No entanto, fitoplasmas pertencentes ao subgrupo $16 \mathrm{SrI}-\mathrm{B}$ somente foram reportados em videiras cultivadas na Itália (Alma et al.,1996). Fitoplasmas pertencentes ao grupo 16SrIII, identificados em plantas de videiras amostradas em São Paulo e no Paraná, através de PCR usando-se iniciadores específicos, também já foram associados com amarelo da videira em algumas regiões vitícolas dos Estados Unidos (Prince et al., 1993; Davis et al., 1998) e de Israel (Orenstein et al., 2001).

A ocorrência de fitoplasmas do grupo $16 \mathrm{SrI}$ e $16 \mathrm{SrIII}$ em plantas de videira coletadas nos Estados de São Paulo e Paraná revela que nestes estados está presente a doença conhecida como amarelo da videira. No entanto, a ausência de fitoplasmas do grupo $16 \mathrm{SrV}$ nas amostras analisadas é um indicativo da não ocorrência da flavescência dourada na região amostrada.

Corrêa \& Boliani (2001) mencionam que a cultura da videira só tomou impulso no Brasil no século XIX, quando foram introduzidas variedades americanas mais rústicas, de maior resistência a pragas e doenças, as quais apresentaram maior adaptação ao ambiente brasileiro. Kuniyuki (2001) relatou que a viticultura nacional se desenvolveu a partir da multiplicação de clones de variedades originárias de países tradicionalmente produtores de uva que enfrentam sérios problemas fitossanitários causados pela ocorrência de viroses. As doenças do tipo amarelo em videira foram relatadas a partir da década de cinqüenta, na Europa (Caudwell, 1957), porém, provavelmente, já ocorriam anteriormente. Partindo-se destas informações e com base nos resultados do presente trabalho que revelaram a ocorrência do amarelo da videira no Brasil, pode-se inferir que esta doença tenha chegado ao Brasil juntamente com os materiais de videira aqui introduzidos, visto que os mesmos são propagados por reprodução vegetativa a partir de estacas. A suposição de que os fitoplasmas detectados nas videiras amostradas em São Paulo e Paraná possam ter sido introduzidos justamente por variedades americanas não pode ser descartada, pois fitoplasmas dos mesmos grupos foram encontrados associados ao amarelo presente nos Estados Unidos e no Brasil. Ainda, como os sintomas provocados por alguns vírus são semelhantes àqueles incitados por fitoplasmas fica a 
suposição de que os fitoplasmas associados ao amarelo da videira possam estar no Brasil há muito tempo e a doença estar sendo atribuída a vírus ou outro agente.

As pesquisas desenvolvidas neste trabalho revelaram a presença do amarelo da videira no território brasileiro e demonstraram que fitoplasmas pertencentes a grupos distintos estão associados com a doença. Estes resultados trouxeram à tona um problema fitossanitário que até este momento praticamente passou desapercebido. Em razão da importância das doenças da videira associadas a fitoplasmas em outros países e da relevância econômica da cultura para o Brasil, o assunto merece maiores investigações. Com relação a isto, alguns pontos podem ser destacados, como a necessidade de se fazer um levantamento mais amplo em vinhedos para dimensionar melhor o problema; confirmar se somente o amarelo ocorre em nossas condições ou se a flavescência dourada também está presente; buscar informações sobre a ocorrência de possíveis vetores do patógeno; pesquisar formas de se obter matrizes sadias, visando a produção de mudas de boa qualidade. Além do aspecto aplicado, o presente trabalho também traz uma contribuição ao conhecimento do papel e da diversidade dos fitoplasmas no agroecossistema brasileiro. 


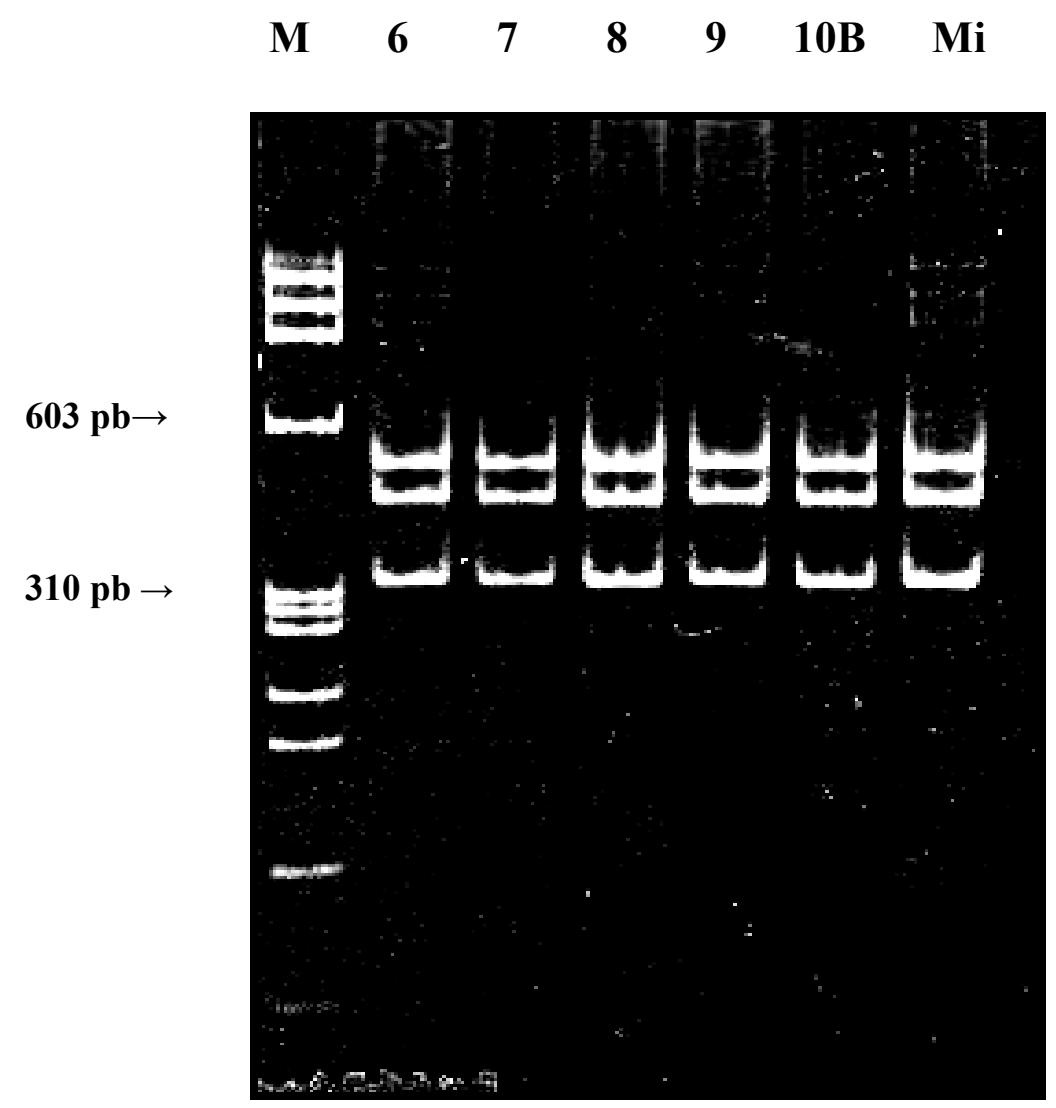

Figura 7- Produtos de digestão obtidos com a enzima KpnI. Análise dos produtos de duplo PCR conduzido com os pares de nucleotídeos P1/P7 e R16 F2n/R2, utilizando DNA extraído de plantas de milho com sintomas de enfezamento, como representante do grupo $16 \mathrm{SrI}$ e DNA extraído de plantas de videira com sintomas de amarelo. $\mathrm{M}=$ padrão de peso molecular, utilizando o marcador ФX174RFHaeIII (1353pb, 1078pb, 872pb, 603pb, 310pb, 271pb, 281pb, 234pb, 194pb, 118pb, 72pb); 6= Benitaka 08.3136, Campinas-SP; 7= Cabernet Franc CF1261, Campinas-SP; 8= Maria LV1459, Jundiaí-SP; 9= Seedling Brasil, Campinas-SP; 10B = Brasil 1780, Marialva-PR; $\mathrm{Mi}=$ milho, representante do grupo $16 \mathrm{SrI}$ 


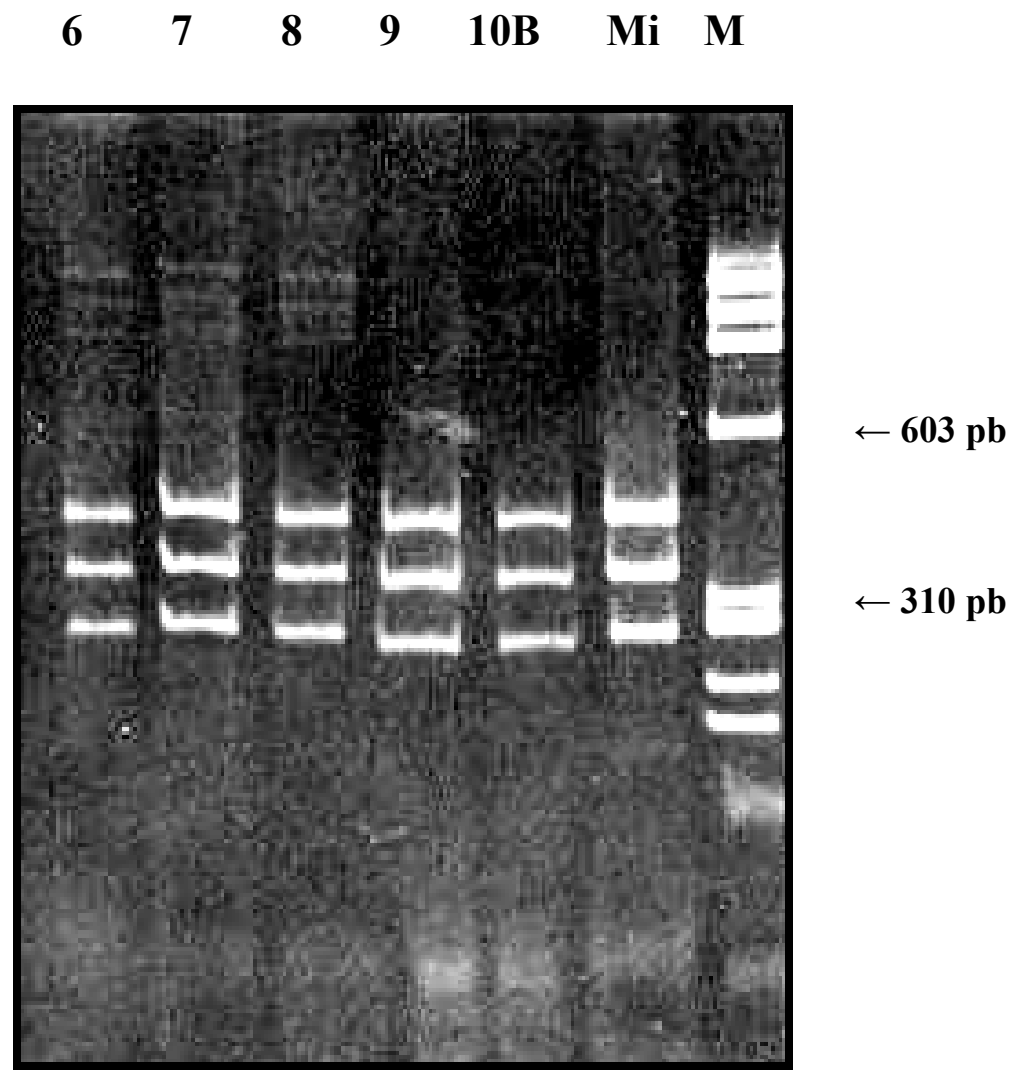

Figura 8- Produtos de digestão obtidos com a enzima RsaI. Análise dos produtos de duplo PCR conduzido com os pares de nucleotídeos P1/P7 e R16 F2n/R2, utilizando DNA extraído de plantas de milho com sintomas de enfezamento, como representante do grupo 16SrI e DNA extraído de plantas de videira com sintomas de amarelo. 6= Benitaka 08.3136, Campinas-SP; 7= Cabernet Franc CF1261, Campinas-SP; 8= Maria LV1459, Jundiaí-SP; 9= Seedling Brasil, Campinas-SP; 10B= Brasil 1780, Marialva-PR; $\mathrm{Mi}=$ milho, representante do grupo 16SrI; $\mathrm{M}=$ padrão de peso molecular, utilizando o marcador ФX174RFHaeIII (1353pb, 1078pb, 872pb, 603pb, 310pb, 271pb, 281pb, $234 \mathrm{pb}, 194 \mathrm{pb}, 118 \mathrm{pb}, 72 \mathrm{pb})$ 


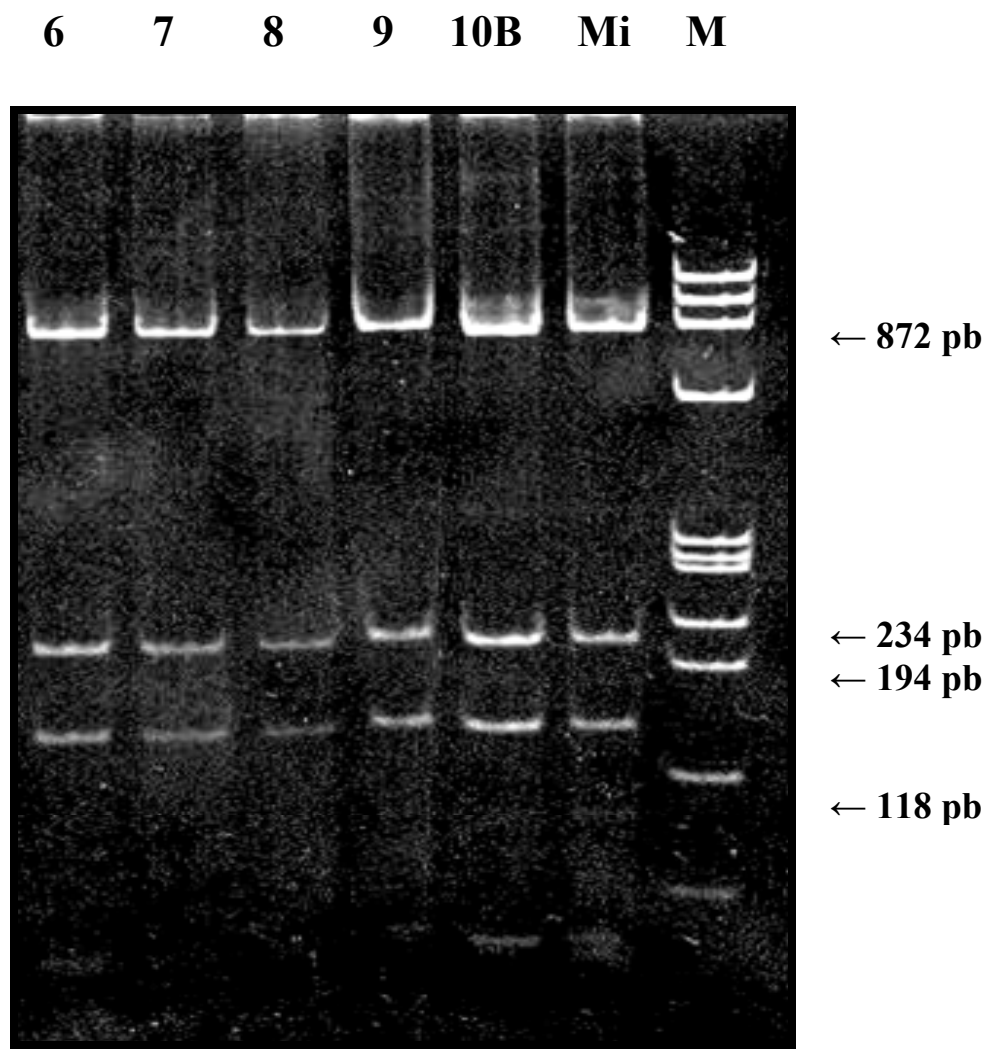

Figura 9- Produtos de digestão obtidos com a enzima HpaII. Análise dos produtos de duplo PCR conduzido com os pares de nucleotídeos P1/P7 e R16 F2n/R2, utilizando DNA extraído de plantas de milho com sintomas de enfezamento, como representante do grupo 16SrI e DNA extraído de plantas de videira com sintomas de amarelo. 6= Benitaka 08.3136, Campinas-SP; 7= Cabernet Franc CF1261, Campinas-SP; 8= Maria LV1459, Jundiaí-SP; 9= Seedling Brasil, Campinas-SP; 10B= Brasil 1780, Marialva-PR; $\mathrm{Mi}=$ milho, representante do grupo 16SrI; $\mathrm{M}=$ padrão de peso molecular, utilizando o marcador ФX174RFHaeIII (1353pb, 1078pb, 872pb, 603pb, 310pb, 271pb, 281pb, $234 \mathrm{pb}, 194 \mathrm{pb}, 118 \mathrm{pb}, 72 \mathrm{pb})$ 


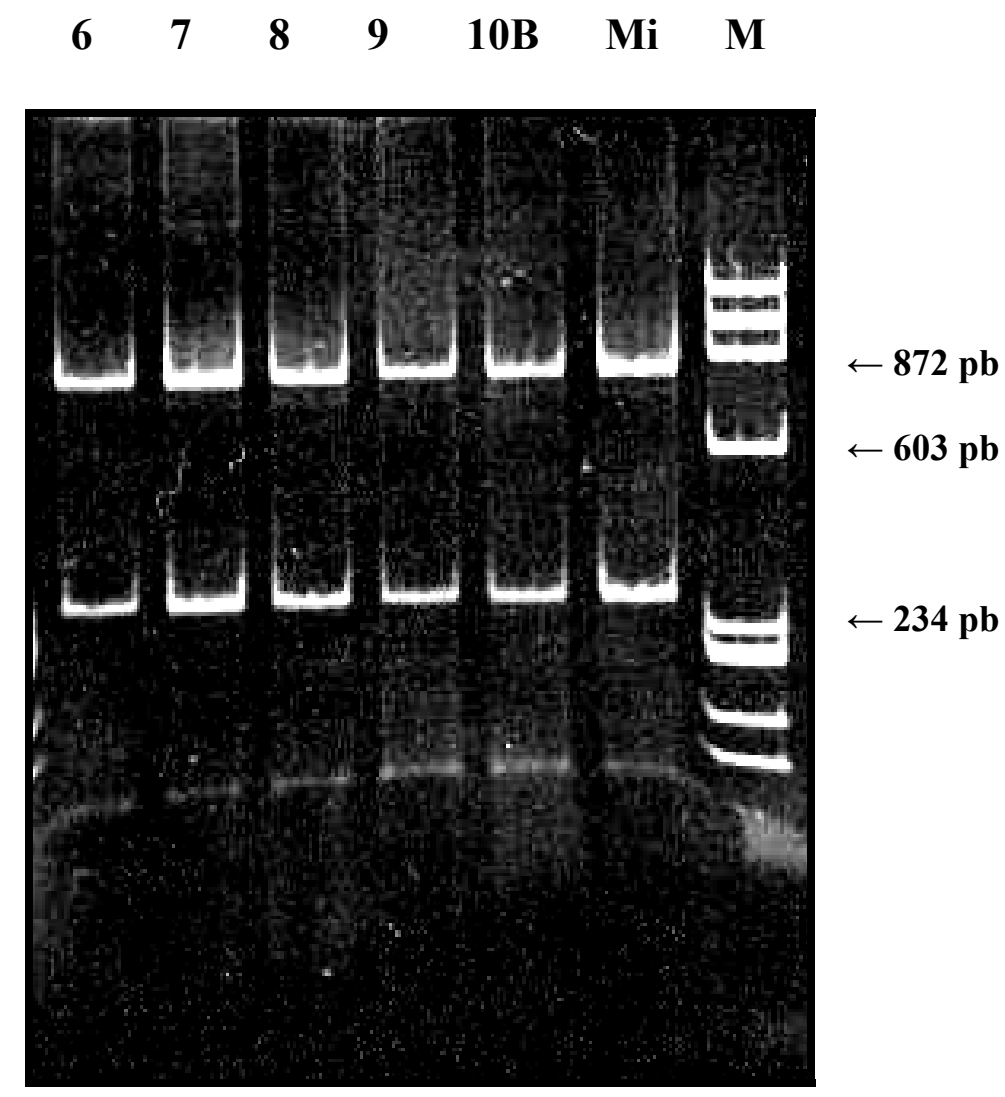

Figura 10- Produtos de digestão obtidos com a enzima Hinfl. Análise dos produtos de duplo PCR conduzido com os pares de nucleotídeos P1/P7 e R16 F2n/R2, utilizando DNA extraído de plantas de milho com sintomas de enfezamento, como representante do grupo $16 \mathrm{SrI}$ e DNA extraído de plantas de videira com sintomas de amarelo. $6=$ Benitaka 08.3136, Campinas-SP; $7=$ Cabernet Franc CF1261, Campinas-SP; 8= Maria LV1459, Jundiaí-SP; 9= Seedling Brasil, Campinas-SP; 10B $=$ Brasil 1780, Marialva-PR; $\mathrm{Mi}=$ milho, representante do grupo $16 \mathrm{SrI} ; \mathrm{M}=$ padrão de peso molecular, utilizando o marcador $\Phi$ X174RFHaeIII (1353pb, 1078pb, 872pb, 603pb, 310pb, 271pb, $281 \mathrm{pb}, 234 \mathrm{pb}, 194 \mathrm{pb}, 118 \mathrm{pb}, 72 \mathrm{pb})$ 


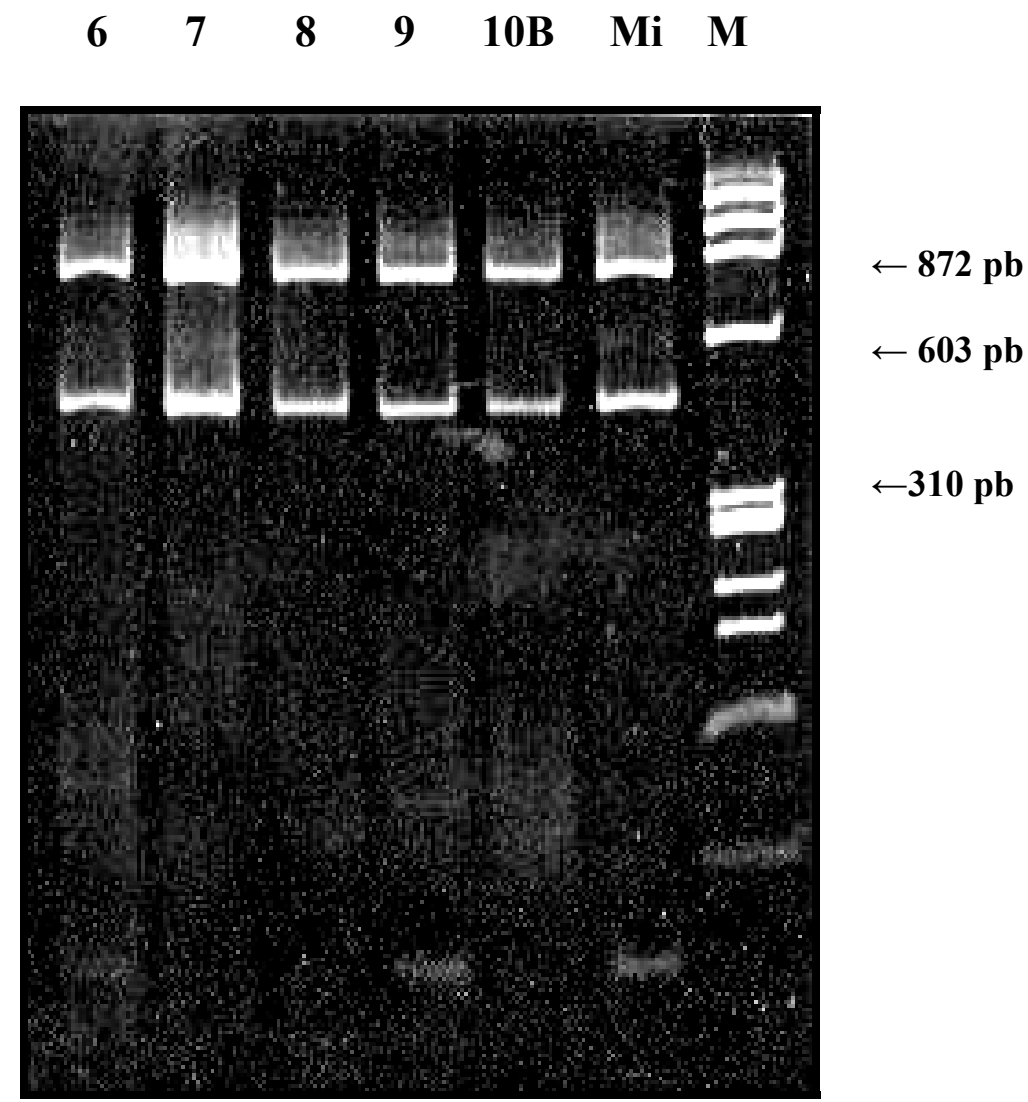

Figura 11- Produtos de digestão obtidos com a enzima MboI. Análise dos produtos de duplo PCR conduzido com os pares de nucleotídeos P1/P7 e R16 F2n/R2, utilizando DNA extraído de plantas de milho com sintomas de enfezamento, como representante do grupo 16SrI e DNA extraído de plantas de videira com sintomas de amarelo. 6= Benitaka 08.3136, Campinas-SP; 7= Cabernet Franc CF1261, Campinas-SP; 8= Maria LV1459, Jundiaí-SP; 9= Seedling Brasil, Campinas-SP; 10B = Brasil 1780, Marialva-PR; $\mathrm{Mi}=$ milho, representante do grupo $16 \mathrm{SrI} ; \mathrm{M}=$ padrão de peso molecular, utilizando o marcador $\Phi$ X174RFHaeIII (1353pb, 1078pb, 872pb, 603pb, 310pb, 271pb, 281pb, 234pb, 194pb, 118pb, 72pb) 


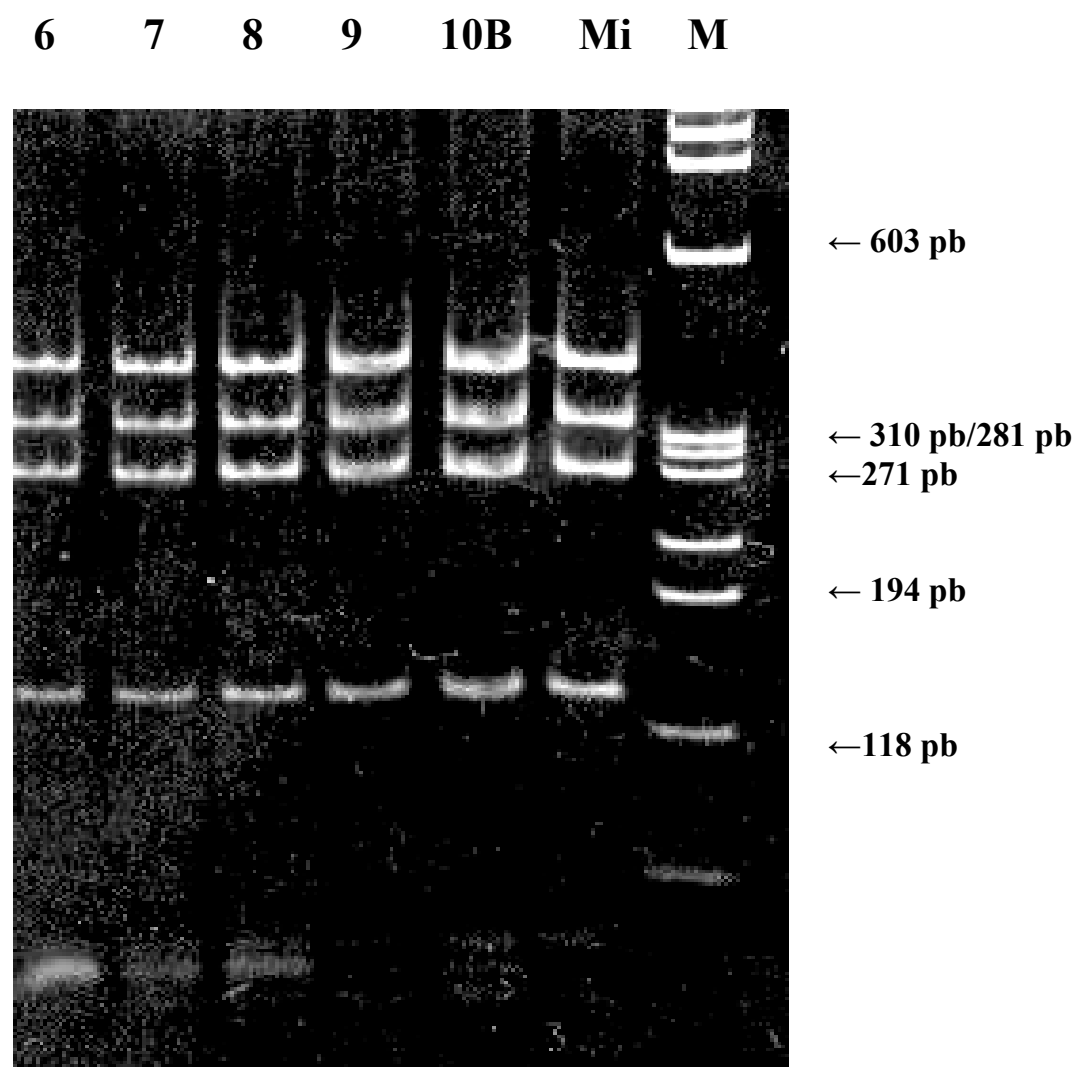

Figura 12- Produtos de digestão obtidos com a enzima MseI. Análise dos produtos de duplo PCR conduzido com os pares de nucleotídeos P1/P7 e R16 F2n/R2, utilizando DNA extraído de plantas de milho com sintomas de enfezamento, como representante do grupo $16 \mathrm{SrI}$ e DNA extraído de plantas de videira com sintomas de amarelo. $6=$ Benitaka 08.3136, Campinas-SP; $7=$ Cabernet Franc CF1261, Campinas-SP; 8= Maria LV1459, Jundiaí-SP; 9= Seedling Brasil, Campinas-SP; 10B = Brasil 1780, Marialva-PR; $\mathrm{Mi}=$ milho, representante do grupo $16 \mathrm{SrI} ; \mathrm{M}=$ padrão de peso molecular, utilizando o marcador $\Phi$ X174RFHaeIII (1353pb, 1078pb, 872pb, 603pb, 310pb, 271pb, $281 \mathrm{pb}, 234 \mathrm{pb}, 194 \mathrm{pb}, 118 \mathrm{pb}, 72 \mathrm{pb})$ 


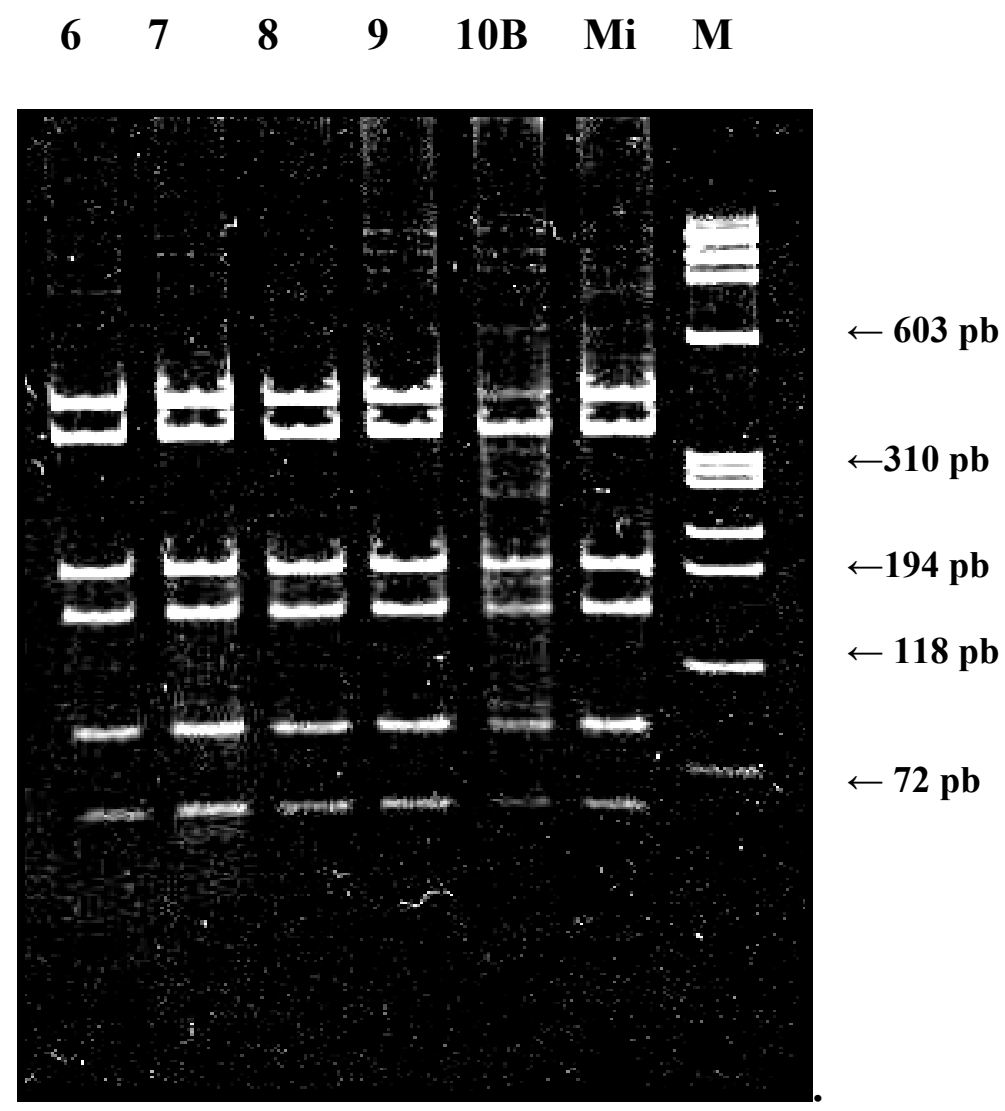

Figura 13- Produtos de digestão obtidos com a enzima AluI. Análise dos produtos de duplo PCR conduzido com os pares de nucleotídeos P1/P7 e R16 F2n/R2, utilizando DNA extraído de plantas de milho com sintomas de enfezamento, como representante do grupo $16 \mathrm{SrI}$ e DNA extraído de plantas de videira com sintomas de amarelo. $6=$ Benitaka 08.3136, Campinas-SP; $7=$ Cabernet Franc CF1261, Campinas-SP; 8= Maria LV1459, Jundiaí-SP; 9= Seedling Brasil, Campinas-SP; 10B $=$ Brasil 1780, Marialva-PR; $\mathrm{Mi}=$ milho, representante do grupo $16 \mathrm{SrI}$; $\mathrm{M}=$ padrão de peso molecular, utilizando o marcador $\Phi$ X174RFHaeIII (1353pb, 1078pb, 872pb, 603pb, 310pb, 271pb, $281 \mathrm{pb}, 234 \mathrm{pb}, 194 \mathrm{pb}, 118 \mathrm{pb}, 72 \mathrm{pb})$ 


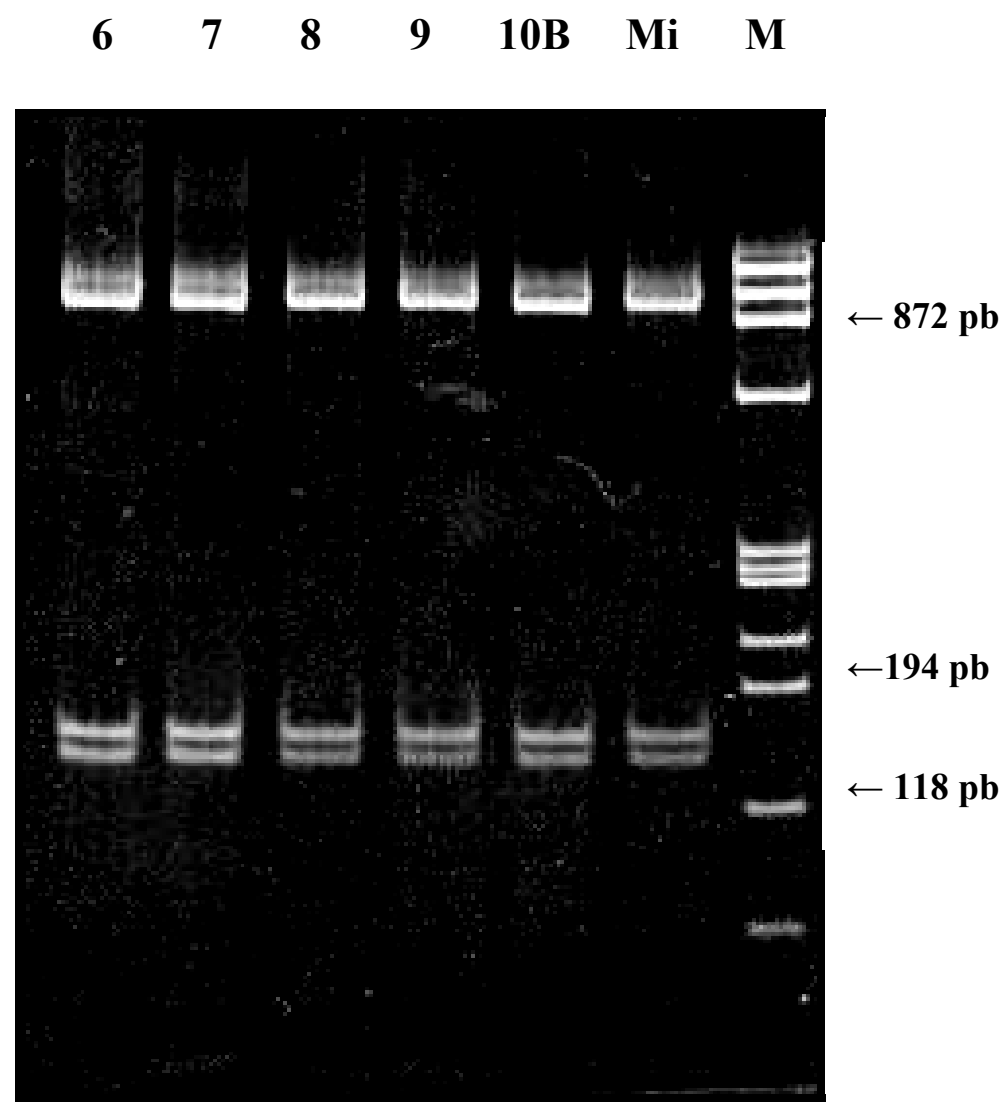

Figura 14- Produtos de digestão obtidos com a enzima HhaI. Análise dos produtos de duplo PCR conduzido com os pares de nucleotídeos P1/P7 e R16 F2n/R2, utilizando DNA extraído de plantas de milho com sintomas de enfezamento, como representante do grupo 16SrI e DNA extraído de plantas de videira com sintomas de amarelo. 6= Benitaka 08.3136, Campinas-SP; 7= Cabernet Franc CF1261, Campinas-SP; 8= Maria LV1459, Jundiaí-SP; 9= Seedling Brasil, Campinas-SP; 10B = Brasil 1780, Marialva-PR; $\mathrm{Mi}=$ milho, representante do grupo $16 \mathrm{SrI} ; \mathrm{M}=$ padrão de peso molecular, utilizando o marcador $\Phi$ X174RFHaeIII (1353pb, 1078pb, 872pb, 603pb, 310pb, 271pb, $281 \mathrm{pb}, 234 \mathrm{pb}, 194 \mathrm{pb}, 118 \mathrm{pb}, 72 \mathrm{pb})$ 


\section{CONCLUSÕES}

Os resultados obtidos neste trabalho permitiram concluir que:

1 A doença conhecida como amarelo da videira está presente em vinhedos instalados nos Estados de São Paulo e Paraná.

2 Fitoplasmas pertencentes aos grupos 16SrI e 16SrIII estão associados com o amarelo da videira ocorrente nos locais amostrados.

3 Os fitoplasmas associados ao amarelo da videira podem ocorrer na forma de infecção mista em um único hospedeiro. 


\section{REFERÊNCIAS BIBLIOGRÁFICAS}

ALMA, A.; DAVIS, R.E.; VIBIO, M.; DANIELLI, A.; BOSCO, D.; ARZONE, A.; BERTACCINI, A. Mixed infection of grapevines in northern Italy by phytoplasmas including 16S rRNA RFLP subgroup 16SrI-B strains previously unreported in this host. Plant Disease, v.80, p.418-421, 1996.

BARROS, T.S.L. Fitoplasmas no Brasil: caracterização molecular via "polymerase chain reaction" and "restriction fragment length polymorphism". Brasília, 1997. 89p. Dissertação (M.S.) - Universidade de Brasília.

CAUDWELL, A. Deux années d'études sur la Flavescence dorée, nouvelle maladie grave de la vigne. Annales de l'Amélioration des Plants, v.12, p. 359-393, 1957.

CAUDWELL, A. Etude sur la madladie du bois noir de la vigne: ses rapports avec la flavescence dorée. Annals of Epiphytology, v.12, p.241-262, 1961.

CAUDWELL, A.; DALMASSO, A. Epidemiology and vectors of grapevine viruses and yellows diseases. Phytopathology Mediterranea, v.24, p.170-176, 1985.

CAUDWELL, A. Bois noir and Vergilbungkrankheit. Other grapevine yellows. In: PEARSON, R.C.; GOHEEN A.C. (Ed.) Compendium of Grapevine diseases, St Paul, MN, USA: Am. Phytopathol. Soc, 1988, p.46-47. 
CAUDWELL, A. Advances in grapevine yellows research since 1990. In: MEETING ICVG 11, Abstracts. Ed. Montreaux, 1993, p.79-83.

CAUDWELL, A.; MARTELLI, G.P. In: MARTELLI, G.P. (Ed.) Graft-transmissible diseases of grapevines: hanbook for detection and diagnosis. Rome: International Council for the Study of Viruses and Virus Diseases of the Grapevine/Food and Agriculture Organization of the United Nations, 1993, p.37-44.

CHAPA, M.G.; MEDINA, V.; VIRUEL, M.A.; LAVIÑA, A.; BATLLE, A. Seasonal detection of pear decline phytoplasma by nested-PCR in different pear cultivars. Plant Pathology, v.52, p.513-520, 2003.

CHIYKOWSKI L.N.; SINHA, R.C. Differentiation of MLO disease by means of symptomatology and vetor transmission. Zentralblatt fur Bakteriologie, Suppl., v.20, p.280-287, 1989.

CONSTABLE, F.E., GIBB, K.S.; SYMONS, R.H. Seasonal distribution of phytoplasmas in Australian grapevines. Plant Pathology, v. 52, p.267-276, 2003.

CORRÊA, L. S.; BOLIANI, A.C. Cultura de uvas de mesa do plantio à comercialização. Ilha Solteira: Ed. Algraf, 2001. 328p.

DAIRE, X.; CLAIR, D.; REINERT, W.; BOUDON-PADIEU, E. Detection and differentiation of grapevine yellows phytoplasmas belonging to the elm yellows group and to the stolbur subgroup by PCR amplification of non-ribossomal DNA. European Journal of Plant Pathology, v.103, p.507-514, 1997. 
DAIRE, X.; BOUDON-PADIEU, E.; BERVILLÉ, A.; SCHNEIDER, B.; CAUDWELL, A. Cloned DNA probes for detection of grapevine flavescence dorée mycoplasmalike organism (MLO). Annals of Applied Biology, v.121, p.95-103, 1992.

DAIRE, X.; CLAIR, D.; LARRUE, J.; BOUDON-PADIEU, E.; ALMA A.; ARZONE, A.; CARRARO, L.; OSLER, R.; REFATTI, E. ; GRANATA, G.; CREDI, R.; TANNE, E.; PEARSON, R.; CAUDWELL, A. Occurrence of diverse MLOs in tissues of grapevine affected by grapevine yellows in different countries. Vitis, v.32, p. 247-248, 1993.

DAVIS, R.E. Fitoplasmas: Fitopatógenos procarióticos sem parede celular habitantes de floema e transmitidos por artrópodos. Revisão Anual de Patologia de Planta v.3, p.1-27, 1995.

DAVIS, R.E.; DALLY, E.L. Revise subgroup classification of group $16 \mathrm{SrV}$ phytoplasmas and placement of flavescence dorée-associated phytoplasmas in two distinct subgroups. Plant Disease, v.85, p.790-797, 2001.

DAVIS, R.E.; JOMANTIENE, R.; DALLY, E.L.; WOLF, T.K. Phytoplasmas associated with grapevine yellows in Virginia belong to group A (tomato big bud phytoplasma subgroup), and group 16SrIII, new subgroup I. Vitis, v.37, p.131-137, 1998.

DAVIS, R.E.; DALLY, E.L.; GUNDERSEN, D.E.; LEE, I.-M.; HABILI, N. “Candidatus Phytoplasma australiense", a new phytoplasma taxon associated with Australian grapevine yellows. International Journal of Systematic Bacteriology, v.47, p.262-269, 1997. 
DEL SERRONE, P.; BARBA, M. Importance of the vegetative stage for phytoplasma detection in yellow-diseased grapevines. Vitis, v. 35, p. 101-102, 1996.

DENG, S.; HIRUKI, C. Amplification of 16S rRNA genes from culturable and nonculturable Mollicutes. Journal of Microbiological Methods, v.14, p.53-61, 1991.

DOI, Y.; TERANAKA, M.; YORA, K.; ASUYAMA, H. Mycoplasma or PLT-grouplike microorganisms found in the phloem elements of plants infected with mulberry dwarf, potato witches'broom, aster yellows, or paulownia witches'broom. Phytopathological Society of Japan, v.33, p.259-266, 1967. Phytopathological Society of Japan, v.33, p.259-266, 1967.

FNP CONSULTORIA \& COMÉRCIO. AGRIANUAL 2004: Anuário da Agricultura Brasileira. São Paulo, p.488-496, 2004.

GALlOTTI, G.J.M.; GRIGOLETTI JÚNIOR, A.; SONEGO, O.R. Controle das doenças da videira. In: ZAMBOLIM, L.; VALE, F.X.R.; MONTEIRO, A.J.A.; COSTA, H. Controle de doenças de plantas fruteiras v.2., p. 939-1023, 2002.

GREEN M.J.; THOMPSON D.A.; MACKENZIE D.J. Easy and efficient DNA extraction from woody plants for the detection of phytoplasmas by polymerase chain reaction. Plant Disease, v.83, p.482-485, 1999.

GUNDERSEN, D.E.; LEE, I.-M. Ultrasensitive detection of phytoplasmas by nestedPCR assays using two universal primers pairs. Phytopathology Mediterranea, v.35, p.144-151, 1996.

HENSON, J.M.; FRENCH, R. The polymerase chain reaction and plant diseases diagnosis. Annual Review of Phytopathology, v.31, p. 81-109, 1993. 
JOHN, M.E. An efficient method for isolation of RNA and DNA from plants containing polyphenolics. Nucleic Acids Research, v.20, p.2381, 1992.

KITAJIMA, E.W. Enfermidade de plantas associadas a organismos do tipo micoplasma. Revisão Anual de Patologia de Plantas, v.2, p.153-174, 1994.

KITAJIMA, E.W. Lista de publicações sobre viroses e enfermidades correlatas de plantas no Brasil (1986-1993). Fitopatologia Brasileira, Supl. esp., 1995.

KUNIYUKI, H. Viroses da videira. In: CORRÊA, L. S.; BOLIANI, A.C. Cultura de uvas de mesa do plantio à comercialização. Ilha Solteira: Ed. Algraf, 2001, p.221235.

LEE, I.M; DAVIS, R.E.; GUNDERSEN-RINDAL, D.E. Phytoplasma: Phytopathogenic Mollicutes. Annual Review of Microbiology, v.54, p.221-255, 2000.

LEE, I.M.; GUNDERSEN-RINDAL, D.E.; HAMMOND, R.W.; DAVIS, R.E. Use of mycoplasmalike organism (MLO) group-especific oligonucleotide primers for nested PCR assay to detect mixed MLO infections in a single host plant. Phytopathology, v.84, p.559-566, 1994.

LEE, I.M.; GUNDERSEN-RINDAL, D.E.; DAVIS, R.E.; BARTOSZIK, I.M. Revised classification scheme of phytoplasma based on RFLP analyses of 16S rDNA and ribossomal protein gene sequences. International Journal of Systematic Bacteriology, v.48, p.1153-1169, 1998.

LEE, I.M.; DAVIS, R.E.; SINCLAIR, W.A.; DEWITT, N.D.; CONTI, M. Genetic relatedness of mycoplasmalike organisms detected in Ulmus spp. in the United States and Italy by means of DNA probes and polymerase chain reactions. Phytopathology, v.83, p.829-833, 1993. 
MARTINI, M.; MURARI, E. Identification and epidemic distribuition of two flavescence dorée-related phytoplasmas in Veneto (Italy). Plant Disease, v.83, p.925-930, 1999.

McCOY, R.E.; CAUDWELL, A.; CHANG, C.J.; CHEN, T.A.; CHIYKOWSKI, L.N.; COUSIN, M.T.; DALE, J.L.; LEEUW, G.T.; GOLINO, D.A.; HACKETT, K.J.; KIRKPATRICK, B.C.; MARWITZ, R.; PETZOLD, H.; SINHA, R.C.; SUGIURA, M.; WHITCOMB, R.F.; YANG, I.L.; ZHU, B.M.; SEEMULLER, E. Plant diseases associated with mycoplasmalike organisms. In: WHITCOMB, R.F.; TULLY, J.G. The Mycoplasmas, v. 5, p.545-640, 1989.

MONTANO, H.G.; DAVIS, R.E.; DALLY, E.L.; PIMENTEL, J.P.; BRIOSO, P.S.T. Identification and phylogenetic analysis of a new phytoplasma from diseased chayote in Brazil. Plant Disease, v.84, p.429-436, 2000.

MONTANO, H.G.; DAVIS, R.E.; DALLY, E.L.; HOGENHOUT, S.; PIMENTEL, J.P.; BRIOSO, P.S.T. Candidatus Phytoplasma brasiliense, a new phytoplasma taxon associated with hibiscus witches'broom disease. International Journal of Systematic and Evolutionary Microbiology, v.51, p. 1109-1118, 2001.

ORENSTEIN, S.; ZAHAVI, T.; WEINTRAUB, P.G. Survey of the distribution of phytoplasma in wine grapes in the Golan Heights, Israel and development of especific primers. Vitis, v.40, p.219-223, 2001.

PEARSON, R.C.; POOL, R.M.; GONSALVES, D.; GOFFINET, M.C. Occurence of flavescence dorée-like symptoms on "White Riesling" grapevines in New York, USA. Phytopathology Mediterranea, v.24, p.82-87, 1985. 
PRINCE, J.P; DAVIS, R.E.; WOLF, T.K.; LEE, I.-M.; MORGEN B.D.; DALLY, E.L.; BERTACCINI, A.; CREDI, R.; BARBA, M. Molecular detection of diverse mycoplasmalike organisms (MLOs) assiciated with grapevine yellows and their classification with aster yellows, X-disease, and elm yellows MLOs. Phytopathology, v.83, p.1130-1137, 1993.

SCHAFF, D.; LEE, I.M.; DAVIS, R.E. Sensitive detection and identification of mycoplasmalike organisms by polymerase chain reaction. Biochemical Biophysical Research Communication, v.186, p.1502-1509, 1992.

SEARS, B.B.; KIRKPATRICK, B.C. Unveiling the evolutionary relationships of plantpathogenic mycoplasmalike organisms. ASM News, v. 60, p.307-312, 1994.

SIMÃO, S. Tratado de Fruticultura. Piracicaba: FEALQ, 1998. 760p.

SMART, C.D.; SCHNEIDER, B.; BLOMQUIST, C.L.; GUERRA, L.J.; HARRISON, N.A.; AHRENS, U.; LORENZ, K.-H.; SEEMÜLLER, E.; KIRKPATRICK, B.C. Phytoplasm-especific PCR primers based on sequences of the 16S-23S rRNA spacer region. Applied and Environmental Microbiology, v.62, p.2988-2993, 1996. 